\title{
Health equity in Iran: A systematic review
}

\author{
Hesam Ghiasvand ${ }^{1}$, Efat Mohamadi ${ }^{2}$, Alireza Olyaeemanesh ${ }^{3,4}$, Mohammad Mehdi Kiani $^{2,5}$, Bahram Armoon ${ }^{6}$, \\ Amirhossein Takian ${ }^{2,4,5 *}$ (1)
}

Received: 3 Feb 2020

Published: 19 Apr 2021

\section{Abstract}

Background: Health inequities are among debatable and challenging aspects of health systems. Achieving equity through social determinants of health approach has been mentioned in most upstream national plans and acts in Iran. This paper reports the findings of a systematic review of the current synthesized evidence on health equity in Iran.

Methods: This is a narrative systematic review. The relevant concepts and terminology in health equity was found through MeSH. We retrieved the relevant studies from PubMed/MedLine, Social Sciences Database, and Google Scholar in English, plus the Jihad University Database (SID), and Google Scholar in Farsi databases from 1979 until the end of January 2018. The retrieved evidence has been assessed primarily based on PICOS criteria and then Ottawa-Newcastle Scale, and CASP for qualitative studies. We used PRISMA flow diagram and a narrative approach for synthesizing the evidence.

Results: We retrieved 172455 studies. Following the primary and quality appraisal process, 114 studies were entered in the final phase of the analysis. The main part (approximately 95\%) of the final phase included cross-sectional studies that had been analyzed through current descriptive inequality analysis indicators, analytical regression, or decomposition-based approaches. The studies were categorized within 3 main groups: health outcomes (40.3\%), health utilization (32\%), and health expenditures $(27 \%)$.

Conclusion: As a part of understanding the current situation of health equity in the policymakers' need to refer the retrieved evidence in this study, they need more inputs specially regarding the social determinants of health approach. It seems that health equity research plan in Iran needs to be redirected in new paths that give appropriate weights to biological, gene-based, environmental and contextbased, economic, social, and political aspects of health as well.

We advocate addressing the aspects of Social Determinant of Health (SDH) in analyzing health inequalities.

Keywords: Health Equity, Health Inequality, Health Care Disparity, Health Care Inequality, Health Social Determinants, Health Care Availability, Health Care Accessibility, Health Disparity, Health Care Utilization

Conflicts of Interest: None declared

Funding: This work was funded by the Health Equity Research Centre, Tehran University of Medical Sciences.

\section{*This work has been published under CC BY-NC-SA 1.0 license. \\ Copyright $\odot$ Iran University of Medical Sciences}

Cite this article as: Ghiasvand H, Mohamadi E, Olyaeemanesh A, Kiani MM, Armoon B, Takian A. Health equity in Iran: A systematic review. Med J Islam Repub Iran. 2021 (19 Apr);35:51. https://doi.org/10.47176/mjiri.35.51

\section{Introduction}

Health equity and equal access to health services for various socioeconomic groups are among ultimate goals of any health system. Nonetheless, the concept of health equity has been contr oversial, rendering an ongoing debate among health policymakers and planners over the past decades (1). Significant inequities in various aspects of health,

Corresponding author: Dr.Amirhossein Takian, takian@tums.ac.ir

1. Health Economics Group, Medical School, Institute of Health Researches, South Cloister Building, University of Exeter, United Kingdom

2. Health Equity Research Center (HERC), Tehran University of Medical Sciences, Tehran, Iran

3. National Institute of Health Research, Tehran University of Medical Sciences (TUMS), Tehran, Iran

4. Department of Management and Health Economics, School of Public Health, Tehran University of Medical Sciences, Tehran, Iran

5. Department of Global Health \& Public Policy, School of Public Health, Tehran University of Medical Sciences, Tehran, Iran

6. Social Determinants of Health Research Center, Saveh University of Medical Sciences, Saveh, Iran ie, health outcomes, utilization of health services, and health financing (2), are major concerns in all contexts, ie, low, middle- and high-income countries .The publication of a series of regular reports began by Black in the 1980s in England, which was followed by other countries, including the United States (3). This was a global turning point in

$\uparrow$ What is "already known” in this topic:

Health inequalities are evident in Iran. Despite various theoretical concepts, measurement methods and hypothetical approaches available to tackle the problem in the country, a comprehensive and national review on the status of health equity is still lacking in Iran.

\section{$\rightarrow$ What this article adds:}

This study systematically synthesizes the existing evidence to assist policymakers understand and realize the dimensions of health equity. Iran needs more efforts toward redirecting the agenda setting for both investigation and action regarding health equity. 
health inequity analysis. Ever since, many studies have focused on the impact of socioeconomic factors on the health status of the community. In addition, health equity has been the subject of many studies from different aspects, ie, availability, accessibility, utilization, healthcare payment and financing, morbidity, and mortality, while studies have focused on children, adolescents and young adults, elderly, women, and different ethnicities across various settings (37).

Given the key role of equity in improving community health, a number of international and national organizations have made continuous efforts to reduce health inequities. For instance, during the last 2 decades, the World Bank (WB), in cooperation with other agencies, eg, the World Health Organization (WHO), have worked with member states to improve the health and nutrition status and demographic indicators as well as protecting the population against the consequences of illness, malnutrition, and high fertility (5). Health equity and equitable access to healthcare services are also strongly endorsed by the Iranian constitution and other upstream policies, eg, various national development plans. Nonetheless, achieving these objectives still remains a big challenge (8-10). Health equity analysis has been a popular research topic at the provincial and national levels during the recent decades in Iran, eg, the 2 rounds of Urban HEART (Health Equity Assessment Research Tool) project in the capital city of Tehran, a collaboration among WHO, Tehran Municipality, and the Ministry of Health and Medical Education (MOHME) (11), Iran's Multiple Indicator Demographic and Health Survey (IrMIDHS) (12), and the Urban and Rural Expenditure-Income Survey (13). These efforts alongside a relative rich body of health equity analysis in the country show us the importance of health equity as a main concern for both academicians and government. Anyway, we need to monitor the trend of health equity researches in the country through a comprehensive lens. This implies on answering the following question:

- What are the main methodological approaches in health equity analysis in the country?

- What dimensions and scopes of health equity have been more addressed, and which ones need to be a part of research agenda for helping policymakers?

To achieve the objectives of health equity, it is pivotal to determine the current status and document the existing studies, plans, and synthesized knowledge about health equity. Nevertheless, comprehensive and national reviews with consistent evidence on health equity status is still lacking in Iran. This study aims to provide the current gap in conducting health equity studies in Iran through a systematic review approach. This implies on synthesizing the evidence for Iranian health policymakers to realize in which dimensions of the health equity the country needs more efforts, and then redirecting the research policy agenda to them.

\section{Methods}

\section{Search Strategy}

This was a systematic review of the literature on health inequity in Iran between 1979 (the beginning of the Islamic revolution) until 01/31/2018. We used the PRISMA flow diagram and a narrative approach for synthesizing the evidence. We searched PubMed/MedLine, Cochrane Library, and Google Scholar in English as well as the Jihad University Database (SID) and Google Scholar in Farsi. Because of the nature of health equity analysis, it can be considered as an interdisciplinary field between health and medical sciences and social sciences. This means that health equity encompasses the health, medical, social, economic, political, environmental, philosophical, religious, and criminal dimensions. Therefore, we approached our search strategies through seeking PubMed/Medline, and Social Sciences Databases, the first of which is a biological, health and medical sciences database, and the second contains all aspects of the social sciences.

We found the MeSH terms for various terms and expressions as presented below:

Health Care Equality, Health Care Fairness, Health Care Utilization, Health Care Accessibility, Health Care Availability, Health Care Affordability, Horizontal Equity in Health Care, Vertical Equity in Health Care, Health Services Equality, Health Services Fairness, Health Services Accessibility, Health Services Availability, Health Services Affordability, Horizontal Equity in Health Services, Vertical Equity in Health Services, Inequality in Health, Disparity in Healthcare, Health Care Inequalities, Inequalities, Healthcare Disparity, Financial Protection in Health, Catastrophic and Impoverishing in Health Services, Fairness in Financial Contribution in Health, Gender Inequality in Health. Appendix presents the search strategy by databases.

\section{Studies Primary Assessment}

Two team members (H.G.H. and E.M.) were responsible for the primary assessment of the studies, and in case of any disagreement, a third person (A.T.) was involved.

The details are provided as follows:

P (Health Problem): Studies that address all aspects of health equity (as mentioned in search strategy keywords above) in Iran.

I (Intervention): No restriction for this criterion. All clinical, social, economic, and cultural interventions in clinical, individual, social, national and macro contextual context were considered.

$\mathrm{C}$ (Comparator): This criterion was also is in line with the intervention and there was no restriction on comparators.

O (Outcomes): Biological, health-related measures, morality, morbidity, quality of life, and wider consequences in the social context of Iran were considered.

S (Study Design): All studies that assessed various aspects of socioeconomic inequalities through descriptive analysis, calculation of regression coefficient for different inequality indicators as well as qualitative, longitudinal, case-control, cohort, and cross-sectional studies were included.

Exclusion Criteria: We excluded the Iranian immigrants living in other countries. In addition, we excluded protocol studies during the final phase .As some national research projects and studies were conducted through collaborations between the international agencies, eg, the World Health 
Organization, with the Iranian national authorities, eg, the Ministry of Health and Medical Education (MoHME), Tehran Municipality, etc., in both Persian and English, we considered them as primary, and if qualified, appraised them qualitatively.

Data Extraction and Study Quality Assessment: We used the Newcastle-Ottawa Scale for the critical appraisal of the remained studies from the primary screening stage. All studies in this stage were nonrandomized controlled trials (non RCTs); thus, we used Newcastle-Ottawa Scale for assessing their quality (14).

In addition, for the critical appraisal of the qualitative studies, a systematic review was done using Cambridge Quality Appraisal tools $(15,16)$.

Critical appraisal was done by B.A. and M.M.K., and any discrepancies were discussed with E.M. The results of the quality appraisal of the studies are included in various tables of summary of articles.

Data Extraction and Synthesis: Data on the included studies were extracted by E.M. and M.M.K. through a checklist that included the author(s) names, year of publication, title of the study, aim(s), study type, sample size, data gathering tools and methods, main results, and conclusions. All data were used to present the results of the current study thorough a narrative synthetic approach.

We categorized the included studies based on 5 characteristics: study design; outcome variables; method of analysis; level of study; and the publication year, as described in Table 1. Most studies were analytical, analyzed service variables (hospitalization, outpatient, paraclinical, pharmacy, etc.), and used concentration index (CI) as a main indicator (Table 1). Because some papers used more than 1 tool in the analysis, the total number of included articles in the Data analysis category was 147 (instead of 114 actual papers included in this review). We present our findings based on the 3 dimensions of equity: health outcomes, utilization, and financing. As previously mentioned, we were faced with a wide range of topics as our main outcomes, and grouping them was a major challenge, so we used the World Bank health equity researchers approach to summarize and present the results in an organized fashion (7).

\section{Results}

Figure 1 summarizes the flowchart of our literature review and data extraction process, based on PRISMA protocol (Fig. 1).

\section{Studies' Characteristics}

A major part (approximately 65\%) of the included studies were analytical that aimed to investigate the association between health outcome(s) inequality with socioeconomics and demographics determinants. Calculating and analyzing the health services (cares) inequality constructed about $30 \%$ of the interested outcomes by researchers. Also, $26.4 \%$ of the study have used Concentration index as their main inequality analysis indicator. About $46.5 \%$ of the studies are national level studies, which means they have used data extracted from national surveys for analyzing health inequality. The main part of the studies $(57 \%)$ has been performed between 2011 through 2015. Details of the studies' characteristics are available in Table 1.

1- Health Outcomes: Investigating the factors that affect health equity outcomes was the main focus in 36 articles (15-60 in Table 2). We included all studies whose focus were life expectancy, mortality, quality of life, and incidence of diseases and health disorders (both mental and physical) in this category. These articles documented that inequality in demographic variables can affect the health outcomes.

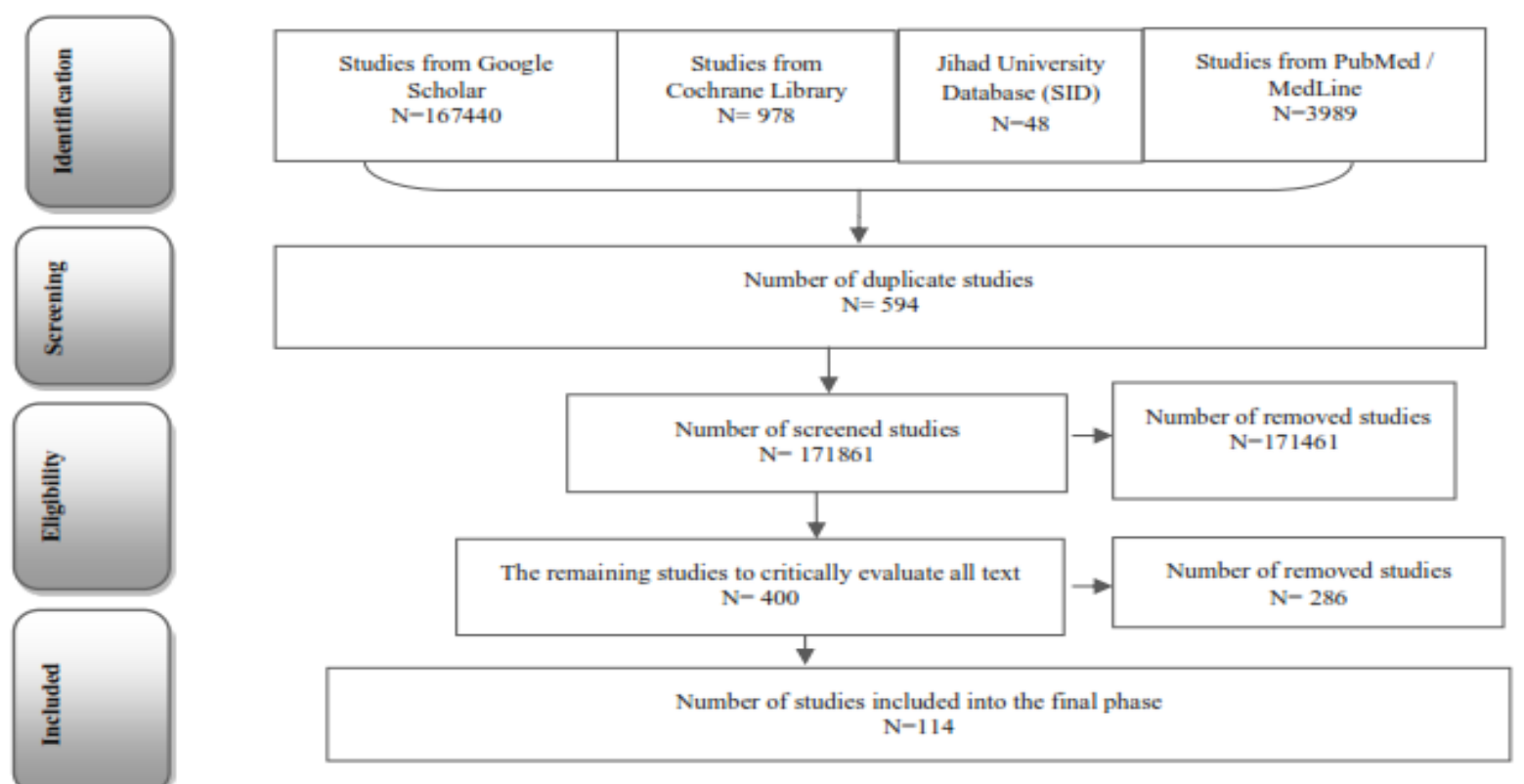

Fig. 1. Data extraction process. 
Table 1. Descriptive characteristics of the 114 selected articles

\begin{tabular}{|c|c|c|c|}
\hline Characteristics & & Number & Proportion $(\%)$ \\
\hline \multirow[t]{6}{*}{ Study design } & Case-control & 2 & 1.75 \\
\hline & Case study & 2 & 1.75 \\
\hline & Descriptive & 27 & 23.68 \\
\hline & Analytical & 74 & 64.91 \\
\hline & Qualitative & 5 & 4.39 \\
\hline & Mix methods & 4 & 3.51 \\
\hline \multirow[t]{8}{*}{ Outcome variables } & Health status, diseases, disorders and illness & 24 & 21.1 \\
\hline & $\begin{array}{l}\text { Resources (bed, medicine, equipment, human and financial re- } \\
\text { sources) }\end{array}$ & 26 & 22.8 \\
\hline & Risky behavior & 2 & 1.8 \\
\hline & Risk Factors in Health & 9 & 7.9 \\
\hline & Mortality (by age) & 10 & 8.8 \\
\hline & Services (inpatient, outpatient, para clinical, pharmacy, etc.) & 34 & 29.8 \\
\hline & Others (pregnancy, inequality, attitudes, health literacy, etc.) & 9 & 7.9 \\
\hline & Others (pregnancy, inequality, attitudes, health literacy, etc.) & & \\
\hline \multirow{7}{*}{$\begin{array}{l}\text { Data analysis } \\
\text { method/ tool/ indica- } \\
\text { tor }\end{array}$} & Concentration Index $(\mathrm{CI})$ & 42 & 28.6 \\
\hline & Gini Coefficient (GC) & 20 & 13.6 \\
\hline & The decomposition of inequality & 27 & 18.4 \\
\hline & Catastrophic health expenditure & 23 & 15.6 \\
\hline & GIS & 4 & 2.7 \\
\hline & $\begin{array}{l}\text { Other (gradient inequality, Robin Hood, Kakwani, dissimilar- } \\
\text { ity, disparity) }\end{array}$ & 24 & 16.3 \\
\hline & Qualitative, Combined & 7 & 4.8 \\
\hline \multirow[t]{3}{*}{ Study Level } & Local & 30 & 26.3 \\
\hline & Provincial & 31 & 27.2 \\
\hline & National & 53 & 46.5 \\
\hline \multirow[t]{4}{*}{ Year of publication } & $2000-2005$ & 3 & 2.6 \\
\hline & $2006-2010$ & 9 & 7.9 \\
\hline & 2011-2015 & 65 & 57.0 \\
\hline & 2016-2018 & 37 & 32.5 \\
\hline
\end{tabular}

2- Healthcare Utilization: A total of 37 (32\%) studies focused on utilization of health services and analyzed the availability, accessibility, and use of health services. For instance, they measured the distribution of health facilities (bed and human resources, etc.,) and access to health care services, which may help improve the distribution policies of health care resources in the country. The results also revealed a meaningful unequal distribution of resources among affluent and deprived areas in Iran and thus the need to redistribute the resources to improve equity in access. Table 3 presents a summary of the objectives and findings of these studies.

3- Health Financing: A total of 31 (27\%) of the studies addressed equity in health financing. The major concern about equitable health financing is inequalities between the poor and the rich. Three main focus areas of equity in health financing are OOP, catastrophic payments (those that exceed a prespecified threshold), and impoverishing payments (those that cause a household to fall below the poverty line). A brief overview of the objectives and results of these studies is presented in Table 4.

\section{Discussion}

More than $90 \%$ of the final included studies had a crosssectional design with a quantitative approach, and only $4 \%$ were qualitative. Analyzing inequality in the preventive, outpatients, inpatients, diagnostic, and other clinical and medical services constructed about $30 \%$ of the studies. The main outcome of interest for Iranian health equity researchers was health resources (human resources, beds, and equipment). There was not any meaningful contribution in analyzing the outside health system contributors to analyzing the health equity.

The findings of our systematic review showed that health equity and its various dimensions were of major research concern in Iran. The included studies mostly assessed the distribution of resources, used macro data (such as the statistical data obtained from the Statistical Center of Iran or the MOHME), and were descriptive. Our review identified 3 main dimensions of equity: health outcomes, utilization, and financing categories. In terms of health outcomes, the studies focused on inequalities in life expectancy; maternal mortality; child mortality; and risk factors, such as diabetes, and obesity; and health indicators, eg, child health, oral health, and specific diseases. Continuous reforms, eg, the expansion of primary health care (PHC) networks, the modified medical education system to respond to increasing demand for expert human resources for health (HRH), and advances in insurance coverage have all contributed to increased life expectancy, decreased mortality, and improved health literacy. However, great challenges still remain, eg, equitable distribution of the health resources, ie, $\mathrm{HRH}$ across the country, especially in deprived and marginalized 
H. Ghiasvand, et al.

Table 2. Summary of articles focusing on equity in health outcomes

\begin{tabular}{|c|c|c|c|c|}
\hline Author(s) & Aims & Study Design & $\begin{array}{l}\text { Newcastle-Ot- } \\
\text { tawa Scale }{ }^{* *}\end{array}$ & Main outcome(s) \\
\hline $\begin{array}{l}\text { Emamian MH, Fateh M, Hosse- } \\
\text { inpoor AR, Alami A, Fotouhi } \\
\text { A.(17) }\end{array}$ & $\begin{array}{l}\text { To describe socio-economic inequal- } \\
\text { ity with obesity and its associated } \\
\text { factors }\end{array}$ & $\begin{array}{l}\text { A cross-sectional } \\
\text { study through analyz- } \\
\text { ing the national sur- } \\
\text { veillance data for } \\
2005\end{array}$ & Good & $\begin{array}{l}\text { Slop index of inequality } \\
\text { Concentration Index } \\
\text { Decomposition inequality in obesity }\end{array}$ \\
\hline $\begin{array}{l}\text { Farzadi F, Ahmadi B, Shariati B, } \\
\text { Alimohamadian M, Mohamad } \\
\text { K.(18) }\end{array}$ & $\begin{array}{l}\text { Looks at the trend in the population } \\
\text { gender ratio from } 1956 \text { to } 2006 \text {, with } \\
\text { a focus on analyzing mortality rates } \\
\text { and hence the overall health of Ira- } \\
\text { nian women }\end{array}$ & $\begin{array}{l}\text { A cohort analysis on } \\
\text { population censuses } \\
\text { in Iran }\end{array}$ & Good & $\begin{array}{l}\text { "Comparison of Mortality in the } 25-34 \\
\text { years age group in 1956-1966 compared } \\
\text { with subsequent decades. }\end{array}$ \\
\hline $\begin{array}{l}\text { Gooshki ES, Rezaei R, Wild } \\
\text { V.(19) }\end{array}$ & $\begin{array}{l}\text { To shed light on the health of mi- } \\
\text { grants in Iran from the perspective of } \\
\text { social } \\
\text { justice }\end{array}$ & A systematic Review & Satisfactory & $\begin{array}{l}\text { Adverse health consequences for popula- } \\
\text { tion }\end{array}$ \\
\hline $\begin{array}{l}\text { Moradi-Lakeh M, Bijari B, } \\
\text { Namiranian N, Olyaeemanesh A- } \\
\text { R, Khosravi A. (20) }\end{array}$ & $\begin{array}{l}\text { To assess the trend of geographical } \\
\text { disparities between rural areas }\end{array}$ & $\begin{array}{l}\text { A trend observational } \\
\text { study }\end{array}$ & Good & $\begin{array}{l}\text { Crude Mortality Rate } \\
\text { Neonatal Mortality rate } \\
\text { Infant Mortality Rate } \\
\text { Under Five Mortality Rate }\end{array}$ \\
\hline $\begin{array}{l}\text { Nedjat S, Hosseinpoor AR, } \\
\text { Forouzanfar MH, Golestan B, } \\
\text { Majdzadeh R. }\end{array}$ & $\begin{array}{l}\text { This study aims to estimate health in- } \\
\text { equality between different socioeco- } \\
\text { nomic groups and its determinants }\end{array}$ & $\begin{array}{l}\text { A cross-sectional } \\
\text { study through a Pop- } \\
\text { ulation survey in } \\
\text { Tehran }\end{array}$ & Good & $\begin{array}{l}\text { Concentration Index } \\
\text { Decomposing socio-economic factors af- } \\
\text { fecting the health status }\end{array}$ \\
\hline $\begin{array}{l}\text { Emamian MH, Zeraati H, Maj- } \\
\text { dzadeh R, Shariati M, Hashemi } \\
\text { H, Jafarzadehpur E, et al. (22) }\end{array}$ & $\begin{array}{l}\text { To investigate economic inequality } \\
\text { and its determinants in near vision, in } \\
\text { a middle-aged population }\end{array}$ & $\begin{array}{l}\text { A cross-sectional } \\
\text { study }\end{array}$ & Good & $\begin{array}{l}\text { The main contributors of gap between } \\
\text { lower and higher socio-economic group } \\
\text { through Oaxaca-Blinder Decomposition }\end{array}$ \\
\hline $\begin{array}{l}\text { Morasae EK, Forouzan AS, Maj- } \\
\text { dzadeh R, Asadi-Lari M, Noor- } \\
\text { bala AA, Hosseinpoor AR. (23) }\end{array}$ & $\begin{array}{l}\text { To measure socioeconomic inequal- } \\
\text { ity in mental health, and then to un- } \\
\text { tangle and quantify the contributions } \\
\text { of potential determinants of mental } \\
\text { health to the measured socioeco- } \\
\text { nomic inequality }\end{array}$ & $\begin{array}{l}\text { A cross-sectional } \\
\text { study through a Pop- } \\
\text { ulation survey in } \\
\text { Tehran }\end{array}$ & Good & $\begin{array}{l}\text { "The overall CI of mental health in Tehran } \\
\text { was }-0.0673(95 \% \text { CI }=-0.070--0.057) \text {. } \\
\text { Decomposition of the CI revealed that eco- } \\
\text { nomic status made the largest contribution } \\
(44.7 \%) \text { to socioeconomic inequality in } \\
\text { mental health. Educational status }(13.4 \%) \text {, } \\
\text { age group }(13.1 \%) \text {, district of residence } \\
(12.5 \%) \text { and employment status }(6.5 \%) \text {." }\end{array}$ \\
\hline $\begin{array}{l}\text { Ramezani Doroh V, Vahedi S, } \\
\text { Arefnezhad M, Kavosi Z, Mo- } \\
\text { hammadbeigi A. (24) }\end{array}$ & $\begin{array}{l}\text { To decompose the health inequality } \\
\text { of people living in Shiraz }\end{array}$ & $\begin{array}{l}\text { A cross-sectional } \\
\text { study through a mul- } \\
\text { tistage-sample survey }\end{array}$ & Good & $\begin{array}{l}\text { Concentration Index for Mental and Gen- } \\
\text { eral Health } \\
\text { Decomposing inequality }\end{array}$ \\
\hline Veisani Y, Delpisheh A. (25) & $\begin{array}{l}\text { To understand the determinants of } \\
\text { socioeconomic inequality of mental } \\
\text { health in the female-headed house- } \\
\text { holds }\end{array}$ & $\begin{array}{l}\text { A cross-sectional } \\
\text { study }\end{array}$ & Satisfactory & $\begin{array}{l}\text { Concentration Index } \\
\text { Decomposing Inequality }\end{array}$ \\
\hline $\begin{array}{l}\text { Amirian H, Poorolajal J, } \\
\text { Roshanaei G, Esmailnasab N, } \\
\text { Moradi G. (26) }\end{array}$ & $\begin{array}{l}\text { The effect of inequity on health out- } \\
\text { comes was investigated via a three- } \\
\text { stage procedure }\end{array}$ & $\begin{array}{l}\text { A cross-sectional } \\
\text { study through a mul- } \\
\text { tistage-sample survey }\end{array}$ & Good & Concentration Index \\
\hline $\begin{array}{l}\text { Khajavi A, Pishgar F, Dehghani } \\
\text { M, Naderimagham S. (27) }\end{array}$ & $\begin{array}{l}\text { To assess inequalities in infant mor- } \\
\text { tality in rural regions }\end{array}$ & $\begin{array}{l}\text { A trend analysis in } \\
\text { national scale }\end{array}$ & satisfactory & $\begin{array}{l}\text { Comparing the decreasing rate of mortality } \\
\text { over the time }\end{array}$ \\
\hline Alizadeh M, Laghousi D.(28) & $\begin{array}{l}\text { To assess the trend of geographical } \\
\text { disparities in child and maternal } \\
\text { mortality rates }\end{array}$ & $\begin{array}{l}\text { A population-based } \\
\text { trend analysis }\end{array}$ & satisfactory & $\begin{array}{l}\text { Index of Disparity in Neonatal, Infant and } \\
\text { Under Five Mortality Rates between } 1999 \\
\text { and } 2013 \text {. }\end{array}$ \\
\hline $\begin{array}{l}\text { Rarani MA, Rashidian A, Arab } \\
\text { M, Khosravi A, Abbasian E.(29) }\end{array}$ & $\begin{array}{l}\text { To measured socioeconomic ine- } \\
\text { quality in under-five mortality in } \\
\text { Iran and across its provinces. }\end{array}$ & $\begin{array}{l}\text { A cross-sectional } \\
\text { study on multiple in- } \\
\text { dicator demographic } \\
\text { and health Survey }\end{array}$ & satisfactory & $\begin{array}{l}\text { Concentration Index for Under Five Mor- } \\
\text { tality Rate. }\end{array}$ \\
\hline Kiadaliri AA. (30) & $\begin{array}{l}\text { To assess gender and social dispari- } \\
\text { ties in Esophagus cancer incidence } \\
\text { across Iran's provinces through } \\
2003-2009\end{array}$ & $\begin{array}{l}\text { A trend analysis by } \\
\text { Iran National Statisti- } \\
\text { cal Centre }\end{array}$ & Satisfactory & $\begin{array}{l}\text { Rate ratios and Kunst and Mackenbach rel- } \\
\text { ative indices of inequality (RIIKM) were } \\
\text { used to assess gender and social inequalities }\end{array}$ \\
\hline $\begin{array}{l}\text { Kiadaliri AA, Saadat S, Shahna- } \\
\text { vazi H, Haghparast-Bidgoli H. } \\
\text { (31) }\end{array}$ & $\begin{array}{l}\text { To assess overall, gender and social } \\
\text { inequalities across Iran's provinces } \\
\text { during 2006-2010. }\end{array}$ & $\begin{array}{l}\text { A time trend prov- } \\
\text { ince-level study }\end{array}$ & Good & $\begin{array}{l}\text { Rate ratio and Kunst and Mackenbach rela- } \\
\text { tive index of inequality were used to assess } \\
\text { overall, gender and social inequalities, re- } \\
\text { spectively. }\end{array}$ \\
\hline $\begin{array}{l}\text { Ghorbani Z, Ahmady AE, } \\
\text { Ghasemi E, Zwi A. (32) }\end{array}$ & $\begin{array}{l}\text { To identify the socioeconomic distri- } \\
\text { bution of perceived oral health } \\
\text { among adults }\end{array}$ & $\begin{array}{l}\text { A cross-sectional } \\
\text { population-based sur- } \\
\text { vey in Tehran }\end{array}$ & Good & $\begin{array}{l}\text { Concentration Index of non-replaced ex- } \\
\text { tracted teeth (NRET), and m perceived den- } \\
\text { tal health }\end{array}$ \\
\hline $\begin{array}{l}\text { Hosseinpoor AR, Mohammad K, } \\
\text { Majdzadeh R, Naghavi M, } \\
\text { Abolhassani F, Sousa A, et al. } \\
\text { (33) }\end{array}$ & $\begin{array}{l}\text { To measure the socioeconomic ine- } \\
\text { quality in infant mortality in Iran }\end{array}$ & $\begin{array}{l}\text { A cross-sectional } \\
\text { study on Iran Demo- } \\
\text { graphic and Health } \\
\text { Survey data }\end{array}$ & Good & $\begin{array}{l}\text { Concentration Index in Infant Mortality } \\
\text { Decomposition Inequality }\end{array}$ \\
\hline
\end{tabular}

areas, suffer from unfavorable economic conditions (11, $128,129)$. Demographic transitions, urbanization, and lifestyle changes have altered the pattern of diseases from communicable to noncommunicable diseases (NCDs), whose risk factors vary, as our included studies revealed, among various socioeconomic groups. Thus, tackling it would require enhancing public health literacy about such risk factors and the ways to prevent them $(45,130,131)$. Regarding utilization of health services, inequalities in the distribution of the health resources, for instance, the existing gap in the available health sector resources, eg, access to specialist physicians, and the distribution of hospital beds, particularly intensive care and burn beds, are among major concerns. Despite the continuous efforts to improve the status, including the recent health transformation plan (HTP) that 


\begin{tabular}{|c|c|c|c|c|}
\hline Author(s) & Aims & Study Design & $\begin{array}{l}\text { Newcastle-Ot- } \\
\text { tawa Scale }\end{array}$ & Main outcome(s) \\
\hline $\begin{array}{l}\text { Hosseinpoor AR, Van Doorslaer } \\
\text { E, Speybroeck N, Naghavi M, } \\
\text { Mohammad K, Majdzadeh R, et } \\
\text { al. (34) }\end{array}$ & $\begin{array}{l}\text { To quantify the determinants' contri- } \\
\text { butions of socioeconomic inequality } \\
\text { in infant mortality }\end{array}$ & $\begin{array}{l}\text { A cross-sectional } \\
\text { study on Iran Demo- } \\
\text { graphic and Health } \\
\text { Survey data }\end{array}$ & Good & Decomposing of Inequality \\
\hline $\begin{array}{l}\text { Almasi-Hashiani A, Sepidarkish } \\
\text { M, Safiri S, Morasae EK, Shadi } \\
\text { Y, Omani-Samani R.(35) }\end{array}$ & $\begin{array}{l}\text { To determine the economic inequal- } \\
\text { ity in history of stillbirth and under- } \\
\text { standing determinants of unequal } \\
\text { distribution of stillbirth in Tehran, } \\
\text { Iran. }\end{array}$ & $\begin{array}{l}\text { A population-based } \\
\text { cross-sectional study }\end{array}$ & Good & $\begin{array}{l}\text { "Decomposition of the Concentration In- } \\
\text { dex of stillbirth }\end{array}$ \\
\hline Rad EH, Khodaparast M. (36) & $\begin{array}{l}\text { Taxation system and health insur- } \\
\text { ance contribution of Iranians were } \\
\text { assessed }\end{array}$ & $\begin{array}{l}\text { A cross-sectional } \\
\text { analysis on data ob- } \\
\text { tained from Iran Sta- } \\
\text { tistical Center. }\end{array}$ & Satisfactory & $\begin{array}{l}\text { Kakwani Index of health insurance contri- } \\
\text { bution }\end{array}$ \\
\hline $\begin{array}{l}\text { Emamian MH, Zeraati H, Maj- } \\
\text { dzadeh R, Shariati M, Hashemi } \\
\text { H, Fotouhi A. (37) }\end{array}$ & $\begin{array}{l}\text { To report the status of the unmet re- } \\
\text { fractive need and the role of eco- } \\
\text { nomic inequality }\end{array}$ & $\begin{array}{l}\text { A cross-sectional } \\
\text { nested case-control }\end{array}$ & Good & $\begin{array}{l}\text { Oaxaca-Blinder decomposition method of } \\
\text { unmet refractive need }\end{array}$ \\
\hline $\begin{array}{l}\text { Hosseinkhani Z, Nedjat S, Afla- } \\
\text { touni A, Mahram M, Majdzadeh } \\
\text { R. (38) }\end{array}$ & $\begin{array}{l}\text { To assess the association of child } \\
\text { maltreatment with socioeconomic } \\
\text { status among schoolchildren }\end{array}$ & $\begin{array}{l}\text { A cross-sectional } \\
\text { study }\end{array}$ & Satisfactory & Concentration Index of child maltreatment \\
\hline $\begin{array}{l}\text { Mansouri A, Rarani MA, Fallahi } \\
\text { M, Alvandi I. (39) }\end{array}$ & $\begin{array}{l}\text { To estimate and decompose educa- } \\
\text { tional inequalities in the prevalence } \\
\text { of IBS }\end{array}$ & $\begin{array}{l}\text { A cross-sectional } \\
\text { study }\end{array}$ & Good & Concentration Index \\
\hline $\begin{array}{l}\text { Fateh M, Emamian MH, Asgari } \\
\text { F, Alami A, Fotouhi A.(40) }\end{array}$ & $\begin{array}{l}\text { To investigate the socioeconomic in- } \\
\text { equality of hypertension in Iran and } \\
\text { to identify its influencing factors }\end{array}$ & $\begin{array}{l}\text { A cross-sectional } \\
\text { study }\end{array}$ & Good & $\begin{array}{l}\text { Slop index of inequality (SII) and concen- } \\
\text { tration index (C) for hypertension. } \\
\text { Oaxaca-Blinder decomposition }\end{array}$ \\
\hline $\begin{array}{l}\text { Moradi G, Ardakani HM, Maj- } \\
\text { dzadeh R, Bidarpour F, Moham- } \\
\text { mad K, Holakouie-Naieni K. } \\
\text { (41) }\end{array}$ & $\begin{array}{l}\text { To determine the socioeconomic sta- } \\
\text { tus (SES) of inequalities and the pro- } \\
\text { portion of the determinants in nonuse } \\
\text { of seat belts in cars and helmets on } \\
\text { motorcycles }\end{array}$ & $\begin{array}{l}\text { A cross-sectional } \\
\text { study }\end{array}$ & Good & $\begin{array}{l}\text { The concentration index, concentration } \\
\text { curve, and comparison of Odds Ratio (OR) } \\
\text { in different SES groups were used to meas- } \\
\text { ure the socioeconomic inequalities using } \\
\text { logistic regression. }\end{array}$ \\
\hline $\begin{array}{l}\text { Veisani Y, Delpisheh A, Moradi } \\
\text { G, Hassanzadeh J, Sayehmiri K. } \\
\text { (42) }\end{array}$ & $\begin{array}{l}\text { To estimate the relationship be- } \\
\text { tween the socioeconomic status and } \\
\text { addiction and mental disorders in su- } \\
\text { icide attempts }\end{array}$ & $\begin{array}{l}\text { A cross-sectional } \\
\text { study }\end{array}$ & Good & $\begin{array}{l}\text { concentration index }(\mathrm{CI}) \text { and decomposing } \\
\text { contribution in inequality }\end{array}$ \\
\hline $\begin{array}{l}\text { Tourani S, Zarezadeh M, Raada- } \\
\text { badi M, Pourshariati F.(43) }\end{array}$ & $\begin{array}{l}\text { Determining regional disparity of } \\
\text { obstetrics and gynecology services } \\
\text { and its association with children and } \\
\text { infant mortality rates }\end{array}$ & $\begin{array}{l}\text { A cross-Sectional } \\
\text { Study }\end{array}$ & Satisfactory & Gini Coefficient \\
\hline $\begin{array}{l}\text { Entezarmahdi R, Majdzadeh R, } \\
\text { Foroushani AR, Nasehi M, } \\
\text { Lameei A, Naieni KH.(44) }\end{array}$ & $\begin{array}{l}\text { To measure inequality of disability } \\
\text { in leprosy }\end{array}$ & $\begin{array}{l}\text { A cross-sectional } \\
\text { study }\end{array}$ & Satisfactory & $\begin{array}{l}\text { extended concentration index decomposi- } \\
\text { tion }\end{array}$ \\
\hline $\begin{array}{l}\text { Moradi G, Mohammad K, Maj- } \\
\text { dzadeh R, Ardakani HM, Naieni } \\
\text { KH.(45) }\end{array}$ & $\begin{array}{l}\text { To determine socioeconomic ine- } \\
\text { qualities in risk factors for NCDs }\end{array}$ & $\begin{array}{l}\text { A trend analysis of } \\
\text { inequality }\end{array}$ & Good & Concentration Index \\
\hline $\begin{array}{l}\text { Naghdi S, Ghiasvand H, Zadeh } \\
\text { NS, Azami S, Moradi T.(46) }\end{array}$ & $\begin{array}{l}\text { To estimate the impact of some } \\
\text { macro-economic factors specially } \\
\text { inequality factors on the Iranian rural } \\
\text { health status }\end{array}$ & $\begin{array}{l}\text { A time trend ecologi- } \\
\text { cal study }\end{array}$ & Satisfactory & Gini Coefficient \\
\hline Kiadaliri AA.(47) & $\begin{array}{l}\text { Investigating social disparities in } \\
\text { breast cancer (BC) and ovarian can- } \\
\text { cer (OC) incidence rates among } \\
\text { women }\end{array}$ & $\begin{array}{l}\text { A time trend prov- } \\
\text { ince-level study }\end{array}$ & Satisfactory & $\begin{array}{l}\text { rate ratio and Kunst and Mackenbach rela- } \\
\text { tive index of inequality were used to assess } \\
\text { social disparities }\end{array}$ \\
\hline $\begin{array}{l}\text { Kia AA, Rezapour A, Khosravi } \\
\text { A, Abarghouei VA.(48) }\end{array}$ & $\begin{array}{l}\text { To assess the socioeconomic ine- } \\
\text { quality in malnutrition in under- } 5 \\
\text { children }\end{array}$ & $\begin{array}{l}\text { A crosse-sectional } \\
\text { study }\end{array}$ & Good & Concentration Index \\
\hline $\begin{array}{l}\text { Moradi G, Moinafshar A, Adabi } \\
\text { H, Sharafi M, Mostafavi F, Bol- } \\
\text { banabad AM. }\end{array}$ & $\begin{array}{l}\text { To evaluate socioeconomic inequal- } \\
\text { ities in the oral health status }\end{array}$ & $\begin{array}{l}\text { A crosse-sectional } \\
\text { study }\end{array}$ & Satisfactory & Concentration Index \\
\hline $\begin{array}{l}\text { Kiadaliri AA, Asadi-Lari M, } \\
\text { Kalantari N, Jafari M, Mahdavi } \\
\text { MRV, Faghihzadeh S.(50) }\end{array}$ & $\begin{array}{l}\text { To examine educational inequalities } \\
\text { among adults }\end{array}$ & $\begin{array}{l}\text { A population based } \\
\text { cross-sectional study }\end{array}$ & Good & $\begin{array}{l}\text { Slope Index of Inequality (SII) and the Rel- } \\
\text { ative Index of Inequality (RII) }\end{array}$ \\
\hline $\begin{array}{l}\text { Emamian MH, Zeraati H, Maj- } \\
\text { dzadeh R, Shariati M, Hashemi } \\
\text { H, Fotouhi A.(51) }\end{array}$ & $\begin{array}{l}\text { To explore inequality in visual im- } \\
\text { pairment }\end{array}$ & A cohort study & Good & Blinder-Oaxaca decomposition \\
\hline $\begin{array}{l}\text { Hosseini M, Olyaeemanesh A, } \\
\text { Ahmadi B, Nedjat S, Farzadi F, } \\
\text { Arab M, et al.(52) }\end{array}$ & $\begin{array}{l}\text { To identify the state of gender equity } \\
\text { in the health sector of the Islamic Re- } \\
\text { public of Iran }\end{array}$ & A mixed method & Satisfactory & $\begin{array}{l}\text { Gender Inequality in different aspects of } \\
\text { health indicators }\end{array}$ \\
\hline $\begin{array}{l}\text { Moradi G, Majdzadeh R, Mo- } \\
\text { hammad K, Malekafzali H, Jafari } \\
\text { S, Holakouie-Naieni K.51 }\end{array}$ & $\begin{array}{l}\text { To determine the status of diabetes } \\
\text { socioeconomic inequality and the } \\
\text { share of determinants of inequalities }\end{array}$ & $\begin{array}{l}\text { A time trend compar- } \\
\text { ative study }\end{array}$ & Good & $\begin{array}{l}\text { Concentration Index } \\
\text { Decomposition Inequality }\end{array}$ \\
\hline $\begin{array}{l}\text { Emamian MH, Fateh M, Gor- } \\
\text { gani N, Fotouhi A.(53) }\end{array}$ & $\begin{array}{l}\text { To describe the socio-economic ine- } \\
\text { quality in stunting and its determi- } \\
\text { nants }\end{array}$ & $\begin{array}{l}\text { A cross-sectional } \\
\text { population-based }\end{array}$ & Good & $\begin{array}{l}\text { Concentration Index } \\
\text { Oaxaca-Blinder Decomposition }\end{array}$ \\
\hline
\end{tabular}

increased total hospital beds in Iran $(132,133)$, the equitable distribution of secondary care resources still remains a big challenge across the country, particularly the remote and marginalized areas. The latter needs great caution to balance the significant costs to improve access at the price of enhancing fair access $(75,82,134)$. As for health financing, the inequality in the distribution of health care costs and households' high exposure level to significant costs of 
H. Ghiasvand, et al.

\begin{tabular}{|c|c|c|c|c|}
\hline Author(s) & Aims & $\begin{array}{l}\text { Study Design } \\
\end{array}$ & $\begin{array}{l}\text { Newcastle-Ottawa } \\
\text { Scale }^{* *}\end{array}$ & Main outcome(s) \\
\hline $\begin{array}{l}\text { Raeisi A, Mehboudi M, Darabi H, } \\
\text { Nabipour I, Larijani B, Mehrdad N, et } \\
\text { al.(54) }\end{array}$ & $\begin{array}{l}\text { To investigate the socioeconomic inequal- } \\
\text { ity of overweight and obesity among the el- } \\
\text { derly }\end{array}$ & prospective cohort study & Good & Concentration Index and the Lorenz curve \\
\hline $\begin{array}{l}\text { Safiri S, Kelishadi R, Heshmat R, } \\
\text { Rahimi A, Djalalinia S, Ghasemian A, } \\
\text { et al.(55) }\end{array}$ & $\begin{array}{l}\text { To describe the socioeconomic inequality } \\
\text { associated with oral hygiene behavior }\end{array}$ & A cross-sectional Study & Good & $\begin{array}{l}\text { Concentration Index (C) and the slope index of in- } \\
\text { equality (SII) }\end{array}$ \\
\hline $\begin{array}{l}\text { Peykari N, Djalalinia S, Qorbani M, } \\
\text { Sobhani S, Farzadfar F, Larijani B. } \\
\qquad(56)\end{array}$ & $\begin{array}{l}\text { Summarizing evidences on associations } \\
\text { between socioeconomic factors and diabe- } \\
\text { tes in Iranian population }\end{array}$ & A systematic review & Good & $\begin{array}{l}\text { The prevalence of diabetes among different socio- } \\
\text { economic and demographic groups. }\end{array}$ \\
\hline $\begin{array}{l}\text { Ravaghi H, Goshtaei M, Olyaee Ma- } \\
\text { nesh A, Abolhassani N, Arabloo J (57) }\end{array}$ & $\begin{array}{l}\text { Obtain a deeper understanding of the de- } \\
\text { velopment of health equity indicators and } \\
\text { identify their implementation challenges }\end{array}$ & A qualitative study & Satisfactory & $\begin{array}{l}\text { Shaping the stakeholder's perspective for different } \\
\text { health inequality indicators }\end{array}$ \\
\hline $\begin{array}{l}\text { Zaboli R, Tourani S, Seyedin SH, Ma- } \\
\text { nesh AO (58) }\end{array}$ & $\begin{array}{l}\text { To determine and prioritize the social de- } \\
\text { terminants of health inequality in Iran }\end{array}$ & A mixed method & Good & $\begin{array}{l}\text { Shaping framework for including SDH approach in } \\
\text { health equity }\end{array}$ \\
\hline $\begin{array}{l}\text { Beheshtian M, Manesh AO, Bonakdar } \\
\text { S, Afzali HM, Larijani B, Hosseini L, } \\
\text { et al.(59) }\end{array}$ & $\begin{array}{l}\text { Determining health equity indicators in } \\
\text { Iran }\end{array}$ & A literature review & Satisfactory & $\begin{array}{l}\text { "52 indicators have been determined as health eq- } \\
\text { uity indicators in five areas including health, social } \\
\text { and human development, economic development, } \\
\text { physical environment and infrastructure and gov- } \\
\text { ernance. " }\end{array}$ \\
\hline $\begin{array}{l}\text { Sadeghipour Roudsari H, Sherafat } \\
\text { Kazemzadeh R, Rezaeie M, De- } \\
\text { rakhshan M.(60) }\end{array}$ & $\begin{array}{l}\text { To assess the knowledge, attitudes and } \\
\text { practices of men, Iranians and Afghan ref- } \\
\text { ugees, regarding reproductive health }\end{array}$ & A cross-sectional Study & Satisfactory & $\begin{array}{l}\text { "Mean scores for knowledge, attitudes and prac- } \\
\text { tices for Iranians were } 4.38 / 30,13.89 / 20 \text { and } \\
12.99 / 31 \text { respectively; for Afghans the scores were } \\
3.79 / 30,11.66 / 20 \text { and } 11.88 / 31 . "\end{array}$ \\
\hline
\end{tabular}

Table 3. Summary of articles focusing on equity in healthcare utilization

\begin{tabular}{|c|c|c|c|c|}
\hline Author(s) & Aims & Study Design & Newcastle-Ottawa Scale $^{* *}$ & Main outcomes \\
\hline $\begin{array}{l}\text { Bidgoli HH, Bogg L, Hasselberg } \\
\text { M.(61) }\end{array}$ & $\begin{array}{l}\text { To assess the distribution of pre-hospital trauma care } \\
\text { facilities reflect the burden of Road Traffic Injury } \\
\text { (RTI) and Mortality (RTM) }\end{array}$ & $\begin{array}{l}\text { Cross-Sectional Ecological } \\
\text { Study }\end{array}$ & Good & Lorenz curves and Gini coefficiet \\
\hline $\begin{array}{l}\text { Mohammadbeigi A, Hassanzadeh } \\
\text { J, Eshrati B, Rezaianzadeh A.(62) }\end{array}$ & $\begin{array}{l}\text { To investigate and decompose the determinants of } \\
\text { healthcare utilization (HCU) }\end{array}$ & $\begin{array}{l}\text { Cross-Sectional Population } \\
\text { based }\end{array}$ & Good & Decomposing Inequality \\
\hline $\begin{array}{l}\text { Mohammadbeigi A, Hassanzadeh } \\
\text { J, Eshrati B, Rezaianzadeh A.(63) }\end{array}$ & $\begin{array}{l}\text { To determine and compare the socioeconomic ineq- } \\
\text { uity in HCU by CI and odds ratio (OR) }\end{array}$ & $\begin{array}{l}\text { Cross-Sectional Population } \\
\text { based }\end{array}$ & Good & Concentration Index \\
\hline $\begin{array}{l}\text { Noroozi M, Rahimi E, Ghisvand } \\
\text { H, Qorbani M, Sharifi H, Noroozi } \\
\text { A, et al.(64) }\end{array}$ & $\begin{array}{l}\text { To explore the relative contributions of inequality in } \\
\text { utilization of NSPs and to decompose it to its deter- } \\
\text { minants }\end{array}$ & Cross-Sectional Survey & Good & Decomposing Inequality \\
\hline $\begin{array}{l}\text { Davari M, Maracy MR, Aslani A, } \\
\text { Bakhshizadeh Z, Khorasani } \\
\text { E.(65) }\end{array}$ & $\begin{array}{l}\text { To evaluate the equity in access to pharmaceutical } \\
\text { services }\end{array}$ & Cross-Sectional & Good & Concentration and Lorenz curves. \\
\hline $\begin{array}{l}\text { Ramandi SD, Niakan L, Aboutor- } \\
\text { abi M, Noghabi JJ, Khammarnia } \\
\text { M, Sadeghi A. (66) }\end{array}$ & $\begin{array}{l}\text { To determine how doctors, paramedics and hospital } \\
\text { beds are distributed in Iran }\end{array}$ & Trend Analysis & Satisfactory & Gini Coefficient \\
\hline $\begin{array}{l}\text { Kiadaliri AA, Najafi B, } \\
\text { Haghparast-Bidgoli H.(67) }\end{array}$ & $\begin{array}{l}\text { To evaluate the distribution of need and access to } \\
\text { health care services among Iran's rural population }\end{array}$ & $\begin{array}{l}\text { Cross-Sectional Ecological } \\
\text { Study }\end{array}$ & Good & $\begin{array}{l}\text { Lorenz Curve, Gini Coefficient, Di } \\
\text { of Dissimilarity }\end{array}$ \\
\hline $\begin{array}{l}\text { Kavosi Z, Mohammadbeigi A, } \\
\text { Ramezani-Doroh V, Hatam N, } \\
\text { Jafari A, Firoozjahantighi A. (68) }\end{array}$ & $\begin{array}{l}\text { To measure horizontal inequity in access to outpatient } \\
\text { services }\end{array}$ & $\begin{array}{l}\text { Cross-Sectional Population } \\
\text { based Survey }\end{array}$ & Good & $\begin{array}{l}\text { Concentration Index } \\
\text { Horizontal Inequity Index }\end{array}$ \\
\hline $\begin{array}{l}\text { Karyani AK, Azami SR, Rezaei } \\
\text { S, Shaahmadi F, Ghazanfari S. } \\
\text { (69) }\end{array}$ & $\begin{array}{l}\text { To investigate the geographical distribution of gyne- } \\
\text { cologists and midwives and to determine their distri- } \\
\text { bution trend }\end{array}$ & Cross- Sectional & Satisfactory & Gini Coefficient \\
\hline $\begin{array}{l}\text { Meshkini AH, Kebriaeezadeh A, } \\
\text { Janghorban MR, Keshavarz K, } \\
\text { Nikfar S.(70) }\end{array}$ & $\begin{array}{l}\text { To analyze the geographic distribution and accessibil- } \\
\text { ity of pharmacies in the municipal territory for both } \\
\text { pedestrians and drivers }\end{array}$ & $\begin{array}{l}\text { A cross-sectional geo- } \\
\text { graphical based study }\end{array}$ & Satisfactory & straight-line distance measuremen \\
\hline $\begin{array}{l}\text { Hajizadeh M, Connelly LB, But- } \\
\text { ler JR, Khosravi A.(71) }\end{array}$ & To analyze inequities of health care utilization & $\begin{array}{l}\text { A cross-sectional popula- } \\
\text { tion-based study }\end{array}$ & Good & $\begin{array}{l}\text { Concentration Index } \\
\text { Horizontal Inequity Index }\end{array}$ \\
\hline $\begin{array}{l}\text { Noroozi M, Sharifi H, Noroozi A, } \\
\text { Rezaei F, Bazrafshan MR, Ar- } \\
\text { moon B.(72) }\end{array}$ & $\begin{array}{l}\text { To explore the contribution of economic status to in- } \\
\text { equality in unprotected sex among people who inject } \\
\text { drugs (PWID) }\end{array}$ & $\begin{array}{l}\text { A cross-sectional behav- } \\
\text { ioral survey in Tehran }\end{array}$ & Good & Oaxaca-Blinder Decomposition \\
\hline $\begin{array}{l}\text { Geravandi S, Najafi M, Rajaee R, } \\
\text { Mahmoudi S, Pakdaman M. (73) }\end{array}$ & $\begin{array}{l}\text { To compare the distribution of burn beds with its dis- } \\
\text { ability-adjusted life years (DALY) in Iran }\end{array}$ & A cross-sectional study & Satisfactory & Gini Coefficient \\
\hline $\begin{array}{l}\text { Sefiddashti SE, Arab M, Gha- } \\
\text { zanfari S, Kazemi Z, Rezaei S, } \\
\text { Karyani AK. (74) }\end{array}$ & $\begin{array}{l}\text { To determine the trend of inequality in the allocation } \\
\text { of human resources in the health sector }\end{array}$ & A cross-sectional study & Satisfactory & Gini Coefficient \\
\hline $\begin{array}{l}\text { Honarmand R, Mozhdehifard M, } \\
\text { Kavosi Z. (75) }\end{array}$ & $\begin{array}{l}\text { To determine distribution of maternal and child health } \\
\text { related workforces }\end{array}$ & A cross-sectional study & Satisfactory & Gini Coefficient \\
\hline $\begin{array}{l}\text { MORADI LM, Ramezani M, } \\
\text { Naghavi M.(76) }\end{array}$ & $\begin{array}{l}\text { To determine the equality in safe delivery indices, i.e., } \\
\text { appropriate place of delivery, type of delivery and } \\
\text { skilled attendant for delivery, and their determinants } \\
\text { in Iran. }\end{array}$ & A cross-sectional study & Good & $\begin{array}{l}\text { Concentration Index for appropria } \\
\text { normal vaginal delivery and skillı } \\
\text { liver }\end{array}$ \\
\hline $\begin{array}{l}\text { Meskarpour-Amiri M, Mehdiza- } \\
\text { deh P, Barouni M, Dopeykar N, } \\
\text { Ramezanian M.(77) }\end{array}$ & $\begin{array}{l}\text { To determine the trend of inequality in the distribution } \\
\text { of intensive care beds }\end{array}$ & A cross-sectional study & Satisfactory & Gini Coefficient for ICU and NII \\
\hline $\begin{array}{l}\text { Jadidi R, Mohammadbeigi A, } \\
\text { Mohammadsalehi N, Ansari H, } \\
\text { Ghaderi E.(78) }\end{array}$ & $\begin{array}{l}\text { To evaluate the inequity in timely vaccination with a } \\
\text { focus on inequities in timeliness }\end{array}$ & A historical cohort study & Good & $\begin{array}{l}\text { Concentration Index of mother an } \\
\text { for timely vaccination }\end{array}$ \\
\hline Masoodi M, Rahimzadeh M.(79) & $\begin{array}{l}\text { To investigate geographical accessibility of residen- } \\
\text { tial areas to health services }\end{array}$ & $\begin{array}{l}\text { A cross-sectional geo- } \\
\text { graphical information sys- } \\
\text { tem }\end{array}$ & Good & $\begin{array}{l}\text { Floating Catchment Area (FCA), } \\
\text { methods and Response Time (RT } \\
\text { nique }\end{array}$ \\
\hline $\begin{array}{l}\text { Emamian MH, Zeraati H, Maj- } \\
\text { dzadeh R, Shariati M, Hashemi H, } \\
\text { Fotouhi A. (80) }\end{array}$ & $\begin{array}{l}\text { To assess the role of economic inequality in the } \\
\text { utilization of eye care services, and to identify its de- } \\
\text { terminants }\end{array}$ & A cohort study & Good & $\begin{array}{l}\text { Oaxaca-Blinder decomposition of } \\
\text { or optometrist Examination. }\end{array}$ \\
\hline $\begin{array}{l}\text { Homaie Rad E, Ghiasi A, } \\
\text { Arefnezhad M, Bayati M. (81) }\end{array}$ & $\begin{array}{l}\text { Inequalities between general physicians' (GP) and } \\
\text { specialists' visits; also, the factors effecting the utili- } \\
\text { zation of visits were determined }\end{array}$ & $\begin{array}{l}\text { A cross-sectional popula- } \\
\text { tion-based study }\end{array}$ & Satisfactory & $\begin{array}{l}\text { Concentration Index of general pr } \\
\text { cialists' visits. }\end{array}$ \\
\hline $\begin{array}{l}\text { Kazemi Karyani A, Kazemi Z, } \\
\text { Shaahmadi F, Arefi Z, Ghazanfari } \\
\text { S.(82) }\end{array}$ & $\begin{array}{l}\text { To investigate the inequality and trend of geographic } \\
\text { accessibility to Pediatricians }\end{array}$ & A time trend analysis & Satisfactory & $\begin{array}{l}\text { Gini Coefficient and Index of Diss } \\
\text { bility to pediatrics }\end{array}$ \\
\hline
\end{tabular}

health care were extensively considered in many studies. We found an unfavorable status of FFCI (concentration,
Gini coefficient, and Kakwani) indices and exposure to health catastrophic costs in the course of the past 2 decades 


\begin{tabular}{|c|c|c|c|c|}
\hline Author(s) & Aims & Study Design & Newcastle-Ottawa Scale ${ }^{* *}$ & Main outcome(s) \\
\hline $\begin{array}{l}\text { Meskarpour-Amiri M, } \\
\text { Dopeykar N, Ameryoun A, } \\
\text { Tavana AM.(83) }\end{array}$ & $\begin{array}{l}\text { To examined inequality in geographical distri- } \\
\text { bution of cardiovascular health services }\end{array}$ & A cross-sectional study & Satisfactory & $\begin{array}{l}\text { Gini Coefficient of CCU beds at } \\
\text { diologist }\end{array}$ \\
\hline $\begin{array}{l}\text { Mobaraki H, Hassani A, } \\
\text { Kashkalani T, Khalilnejad R, } \\
\text { Chimeh EE.(84) }\end{array}$ & $\begin{array}{l}\text { To assess distribution of all human resources } \\
\text { in public sector of the country }\end{array}$ & A cross-sectional study & Satisfactory & $\begin{array}{l}\text { Gini Coefficient and Rabin hc } \\
\text { dexes for human resources distr }\end{array}$ \\
\hline $\begin{array}{l}\text { Omrani-Khoo H, Lotfi F, Sa- } \\
\text { fari H, Jame SZB, Moghri J, } \\
\text { Shafii M. (85) }\end{array}$ & $\begin{array}{l}\text { To examine both equality and equity in re- } \\
\text { sources distribution }\end{array}$ & A cross-sectional study & Good & $\begin{array}{l}\text { Gini Coefficient and Rabin ho } \\
\text { Concentration Index of hemoc } \\
\text { beds }\end{array}$ \\
\hline $\begin{array}{l}\text { Sari AA, Rezaei S, Rad EH, } \\
\text { Dehghanian N, Chavehpour } \\
\text { Y. (86) }\end{array}$ & $\begin{array}{l}\text { To investigate the disparity in the distribution } \\
\text { of health physical resources }\end{array}$ & $\begin{array}{l}\text { A cross-sectional retro- } \\
\text { spective study }\end{array}$ & Good & $\begin{array}{l}\text { Gini Coefficient, Gaswirth ind } \\
\text { Index of Dissimilarity of Healtl } \\
\text { ical resources }\end{array}$ \\
\hline $\begin{array}{l}\text { Mohammadbeigi A, Arsang- } \\
\text { jang S, Mohammadsalehi N, } \\
\text { Anbari Z, Ghaderi E. (87) }\end{array}$ & $\begin{array}{l}\text { To estimate the inequity related to the educa- } \\
\text { tional level of parents on the access and utili- } \\
\text { zation of oral health care }\end{array}$ & A cross-sectional study & Good & $\begin{array}{l}\text { concentration }(\mathrm{C}) \text { index of ineq } \\
\text { lated to the educational level of } 1 \\
\text { on the access and utilization ' } \\
\text { health care }\end{array}$ \\
\hline $\begin{array}{l}\text { Rad EH, Kavosi Z, } \\
\text { Arefnezhad M.(88) }\end{array}$ & $\begin{array}{l}\text { To describe inequality in dental care utiliza- } \\
\text { tion in Iran }\end{array}$ & $\begin{array}{l}\text { A cross-sectional popu- } \\
\text { lation-based study }\end{array}$ & Good & $\begin{array}{l}\text { concentration index of dental c: } \\
\text { lization in Iran }\end{array}$ \\
\hline $\begin{array}{l}\text { Hatam N, Zakeri M, Sadeghi } \\
\text { A, Ramandi SD, Hayati R, } \\
\text { Siavashi E.(89) }\end{array}$ & $\begin{array}{l}\text { To assess the distribution of hospital beds in } \\
\text { Shiraz in } 2014\end{array}$ & $\begin{array}{l}\text { A retrospective cross- } \\
\text { sectional study }\end{array}$ & Satisfactory & Gini Coefficient of hospital ber \\
\hline $\begin{array}{l}\text { Ameryoun A, Meskarpour- } \\
\text { Amiri M, Dezfuli-Nejad ML, } \\
\text { Khoddami-Vishteh H, } \\
\text { Tofighi S.(90) }\end{array}$ & $\begin{array}{l}\text { to evaluate the inequality of geographical dis- } \\
\text { tribution of non-cardiac intensive care beds }\end{array}$ & A cross-sectional study & Satisfactory & $\begin{array}{l}\text { geographical distribution of } \mathrm{n} \\
\text { diac intensive care beds in Irar } \\
\text { the Gini coefficient }\end{array}$ \\
\hline $\begin{array}{l}\text { Hashemi H, Rezvan F, } \\
\text { Fotouhi A, Khabazkhoob M, } \\
\text { Gilasi H, Etemad K, et al. } \\
\text { (91) }\end{array}$ & $\begin{array}{l}\text { To investigate distribution of the cataract sur- } \\
\text { gical }\end{array}$ & A cross-sectional study & Satisfactory & $\begin{array}{l}\text { Concentration Index of Catara } \\
\text { gery per } 1 \text { million population }\end{array}$ \\
\hline $\begin{array}{l}\text { Reshadat S, Saedi S, } \\
\text { Zangeneh A, Ghasemi S, Gi- } \\
\text { lan N, Karbasi A, et al. (92) }\end{array}$ & $\begin{array}{l}\text { To analyze the spatial accessibility to urban } \\
\text { primary-care centers of the population in Ker- } \\
\text { manshah city, Islamic Republic of Iran }\end{array}$ & $\begin{array}{l}\text { A descriptive-analyti- } \\
\text { cal study over } 3 \text { time } \\
\text { periods }\end{array}$ & Good & $\begin{array}{l}\text { The analysis was based on a st } \\
\text { radius of } 750 \mathrm{~m} \text { distance from } \\
\text { centers, walking speed of } 1 \mathrm{~m} / \mathrm{s} \text { a } \\
\text { sired access time to health cen } \\
12.5 \text { mins. }\end{array}$ \\
\hline $\begin{array}{l}\text { Rezaei S, Karyani A, Fallah } \\
\text { R, Matin B. (93) }\end{array}$ & $\begin{array}{l}\text { To evaluate inequalities in the geographical } \\
\text { distribution of human and physical resources } \\
\text { in the health sector }\end{array}$ & A cross-sectional study & Satisfactory & Gini coefficient for human reso \\
\hline $\begin{array}{l}\text { Chavehpour Y, Rashidian A, } \\
\text { Raghfar H, Emamgholipour } \\
\text { sefiddashti S, Maroofi A.(94) }\end{array}$ & $\begin{array}{l}\text { To assesses the 'inverse care law' hypothesis: } \\
\text { whether hospitals tended to be built in the rel- } \\
\text { atively better-off areas through the time }\end{array}$ & $\begin{array}{l}\text { A longitudinal time-se- } \\
\text { ries study }\end{array}$ & Good & $\begin{array}{l}\text { Gini Coefficient of public and } \\
\text { beds. }\end{array}$ \\
\hline $\begin{array}{l}\text { Nemati R, Seyedin H, Ne- } \\
\text { mati A, Sadeghifar J, Nasiri } \\
\text { AB, Mousavi SM, et al. (95) }\end{array}$ & $\begin{array}{l}\text { To examine the disparities in access to health } \\
\text { care services }\end{array}$ & A cross-sectional study & Satisfactory & $\begin{array}{l}\text { Scalogram analysis model to ac } \\
\text { health care services. }\end{array}$ \\
\hline $\begin{array}{l}\text { Yari A, Nedjat S, Asadi-Lari } \\
\text { M, Majdzadeh R (96) }\end{array}$ & $\begin{array}{l}\text { Gaining a deeper understanding of people's } \\
\text { perception on inequality of health and its de- } \\
\text { terminants }\end{array}$ & A qualitative & Good & $\begin{array}{l}\text { "Consensus on social, ment: } \\
\text { physical health inequality }\end{array}$ \\
\hline $\begin{array}{l}\text { Mohammadi S, Gargari SS, } \\
\text { Fallahian M, Källestål C, } \\
\text { Ziaei S, Essén B.(97) }\end{array}$ & $\begin{array}{l}\text { To investigate whether care quality for mater- } \\
\text { nal near miss (MNM) differed between Irani- } \\
\text { ans and Afghans and identify potential pre- } \\
\text { ventable attributes of MNM }\end{array}$ & cross-sectional study & Good & $\begin{array}{l}\text { risk of maternal near miss (MN] } \\
\text { suboptimal care among Afghan } \\
\text { Iranians }\end{array}$ \\
\hline
\end{tabular}

Table 4. Summary of articles focusing on equity in health financing

\begin{tabular}{|c|c|c|c|c|}
\hline Citation & Aims & Study Design & $\begin{array}{l}\text { Newcastle-Ottawa } \\
\text { Scale }{ }^{* *}\end{array}$ & Summary Results \\
\hline $\begin{array}{l}\text { Rezapour A, } \\
\text { Arabloo J, Tofighi } \\
\text { S, Alipour V, } \\
\text { Sepandy M, } \\
\text { Mokhtari P, et } \\
\text { al.(98) }\end{array}$ & $\begin{array}{l}\text { To determine the equity in health care } \\
\text { payments and determining factors among } \\
\text { households }\end{array}$ & A cross-sectional study & Good & $\begin{array}{l}\text { Catastrophic and Impov } \\
\text { ing Health care expenditu }\end{array}$ \\
\hline $\begin{array}{l}\text { Rezapour A, } \\
\text { Ghaderi H, Azar } \\
\text { FE, Larijani B, } \\
\text { Gohari MR.(99) }\end{array}$ & $\begin{array}{l}\text { To determine the effects of OOP payment } \\
\text { for health care services on households }\end{array}$ & A cross-sectional study & Good & $\begin{array}{l}\text { Concentration Index fo } \\
\text { pacity to pay and healt } \\
\text { payments }\end{array}$ \\
\hline $\begin{array}{l}\text { Zare H, Trujillo AJ, } \\
\text { Driessen J, } \\
\text { Ghasemi M, } \\
\text { Gallego G. (100) }\end{array}$ & $\begin{array}{l}\text { Inequalities assessment of health care ex- } \\
\text { penditures }\end{array}$ & A longitudinal study & Good & $\begin{array}{l}\text { Kakwani Index of heal } \\
\text { penditures }\end{array}$ \\
\hline $\begin{array}{l}\text { Davari M, Kheyri } \\
\text { M, Nourbakhsh } \\
\text { SMK, Khadivi R. } \\
\text { (101) }\end{array}$ & $\begin{array}{l}\text { To evaluate households' health financial } \\
\text { protection in different quintiles after im- } \\
\text { plementation of family physician. }\end{array}$ & A time trend study & Satisfactory & $\begin{array}{l}\text { Comparison between dif } \\
\text { socio-economic group b } \\
\text { Square }\end{array}$ \\
\hline
\end{tabular}

in Iran. Despite notable OOP reduction after the HTP implementation, the still high OOP remains a considerable challenge in Iran. Also, citizens in lower socioeconomic quintiles maybe prone to more severe financial hardship due to health expenses, all of which demand greater atten- 
H. Ghiasvand, et al.

\begin{tabular}{|c|c|c|c|c|}
\hline Citation & Aims & Study Design & $\begin{array}{l}\text { Newcastle-Ottawa } \\
\text { Scale }^{* *}\end{array}$ & Summary Results \\
\hline $\begin{array}{l}\text { Khammarnia M, Keshtkaran } \\
\text { A, Kavosi Z, Hayati R.(102) }\end{array}$ & $\begin{array}{l}\text { To investigate the households' im- } \\
\text { poverishment due to the healthcare } \\
\text { costs }\end{array}$ & A cross-sectional study & Satisfactory & $\begin{array}{l}\text { Health care expenditure } \mathrm{i} \\
\text { ishing effect }\end{array}$ \\
\hline $\begin{array}{l}\text { Delavari H, Keshtkaran A, } \\
\text { Setoudehzadeh F. (103) }\end{array}$ & $\begin{array}{l}\text { To determine the percentage of } \\
\text { households with cancer patients that } \\
\text { face catastrophic health expendi- } \\
\text { tures. }\end{array}$ & A cross-sectional study & Satisfactory & Catastrophic health expendi \\
\hline $\begin{array}{l}\text { Kavosi Z, Rashidian A, } \\
\text { Pourreza A, Majdzadeh R, } \\
\text { Pourmalek F, Hosseinpour } \\
\text { AR, et al. (104) }\end{array}$ & $\begin{array}{l}\text { To assessed change in household } \\
\text { catastrophic health care expenditures }\end{array}$ & $\begin{array}{l}\text { A longitudinal population- } \\
\text { based study }\end{array}$ & Good & $\begin{array}{l}\text { The proportion of househol } \\
\text { catastrophic health exp } \\
(\mathrm{CHE})\end{array}$ \\
\hline $\begin{array}{l}\text { Fazaeli AA, Seyedin H, } \\
\text { Moghaddam AV, Delavari A, } \\
\text { Salimzadeh H, Varmazyar H, } \\
\text { et al.(105) }\end{array}$ & $\begin{array}{l}\text { To present a trend analysis for the } \\
\text { indicators related to fairness in } \\
\text { healthcare's financial burden }\end{array}$ & A time trend study & Satisfactory & $\begin{array}{l}\text { "The percentage of people v } \\
\text { astrophic Health Expenditur } \\
\text { Fairness in Financial Contril }\end{array}$ \\
\hline $\begin{array}{l}\text { Juyani Y, Hamedi D, Jebeli } \\
\text { SSH, Qasham M.(106) }\end{array}$ & $\begin{array}{l}\text { To investigate on what extent } \\
\text { Multiple sclerosis patients face } \\
\text { catastrophic costs. }\end{array}$ & A cross-sectional study & Satisfactory & Ratio of catastrophic costs \\
\hline $\begin{array}{l}\text { Hajizadeh M, Connelly } \\
\text { LB.(107) }\end{array}$ & $\begin{array}{l}\text { To examine the progressivity of } \\
\text { health insurance premiums and } \\
\text { consumer co-payments }\end{array}$ & A time trend analysis & Good & Kakwani Progressivity Indic \\
\hline $\begin{array}{l}\text { Hajizadeh M, Nghiem } \\
\text { HS.(108) }\end{array}$ & $\begin{array}{l}\text { To provide a understanding about } \\
\text { the inequality and determinants of } \\
\text { the CHE for hospital services }\end{array}$ & A cross-sectional study & Good & $\begin{array}{l}\text { out-of-pocket expenditure } \\
\text { and the related cata } \\
\text { expenditure (CE) for } \\
\text { services }\end{array}$ \\
\hline $\begin{array}{l}\text { Reshadat S, Najafi F, Karami- } \\
\text { Matin B, Soofi M, Barfar E, } \\
\text { Rajabi-Gilan N, et al. (109) }\end{array}$ & $\begin{array}{l}\text { To measure the financial protection } \\
\text { against CHE among hospitalized } \\
\text { patients }\end{array}$ & A cross-sectional study & Satisfactory & $\begin{array}{l}\text { Mean of Out-of-Pocket Pay } \\
\text { Catastrophic health Expendi }\end{array}$ \\
\hline $\begin{array}{l}\text { Ghorbanian A, Rashidian A, } \\
\text { Lankarani KB, Kavosi Z. } \\
\text { (110) }\end{array}$ & $\begin{array}{l}\text { To estimate the pooled prevalence of } \\
\text { CHE in Iran and identifying }\end{array}$ & $\begin{array}{l}\text { A systematic review and } \\
\text { meta-analysis }\end{array}$ & Good & $\begin{array}{l}\text { Pooled Prevalence of Cata } \\
\text { Health Expenditure }\end{array}$ \\
\hline $\begin{array}{l}\text { Ghoddoosinejad J, Jannati A, } \\
\text { Gholipour K, Baghestan } \\
\text { EB.(111) }\end{array}$ & $\begin{array}{l}\text { To calculate households encountered } \\
\text { with catastrophic healthcare expend- } \\
\text { itures }\end{array}$ & A cross-sectional study & Satisfactory & $\begin{array}{l}\text { Rate of households encoun } \\
\text { catastrophic health expendit }\end{array}$ \\
\hline $\begin{array}{l}\text { Mansouri A, Emamian MH, } \\
\text { Zeraati H, Hashemi H, Fotouhi } \\
\text { A.(112) }\end{array}$ & $\begin{array}{l}\text { To estimate and decompose } \\
\text { economic inequality in presenting } \\
\text { visual acuity }\end{array}$ & A cohort study & Good & Concentration Index \\
\hline $\begin{array}{l}\text { Kavosi Z, Keshtkaran A, } \\
\text { Hayati R, Ravangard R, } \\
\text { Khammarnia M. (113) }\end{array}$ & $\begin{array}{l}\text { Investigated the Household } \\
\text { Financial Contributions to the health } \\
\text { system }\end{array}$ & A cross-sectional study & Good & $\begin{array}{l}\text { Fairness Financial Con } \\
\text { Index }\end{array}$ \\
\hline $\begin{array}{l}\text { Piroozi B, Moradi G, Nouri B, } \\
\text { Bolbanabad AM, Safari H. } \\
\text { (114) }\end{array}$ & $\begin{array}{l}\text { Explore the percentage of } \\
\text { households facing CHE after the } \\
\text { implementation of HSEP }\end{array}$ & A cross-sectional study & Good & Catastrophic Health Expend \\
\hline $\begin{array}{l}\text { Rarani MA, Rashidian A, } \\
\text { Khosravi A, Arab M, } \\
\text { Abbasian E, Morasae } \\
\text { EK.(115) }\end{array}$ & $\begin{array}{l}\text { Decompose inequality in neonatal } \\
\text { mortality into its contributing factors }\end{array}$ & $\begin{array}{l}\text { A comparative longitudinal } \\
\text { study }\end{array}$ & Good & $\begin{array}{l}\text { Inequality in neonatal mor1 } \\
\text { normalized Concertation Inc }\end{array}$ \\
\hline $\begin{array}{l}\text { Daneshkohan A, Karami M, } \\
\text { Najafi F, Matin BK.(116) }\end{array}$ & $\begin{array}{l}\text { To estimate FFCI and quantify } \\
\text { extent of catastrophic household } \\
\text { heath expenditures }\end{array}$ & A cross-sectional study & Good & $\begin{array}{l}\text { The proportion of househol } \\
\text { catastrophic health expendit }\end{array}$ \\
\hline $\begin{array}{l}\text { Moghadam MN, Banshi M, } \\
\text { Javar MA, Amiresmaili M, } \\
\text { Ganjavi S.(117) }\end{array}$ & $\begin{array}{l}\text { Measure percentage of Iranian } \\
\text { households exposed to catastrophic } \\
\text { health expenditures }\end{array}$ & A cross-sectional study & Good & $\begin{array}{l}\text { Catastrophic Health Exp } \\
\text { Ratio }\end{array}$ \\
\hline $\begin{array}{l}\text { Abolhallaje M, Hasani S, } \\
\text { Bastani P, Ramezanian M, } \\
\text { Kazemian M.(118) }\end{array}$ & $\begin{array}{l}\text { To identify measures of fair } \\
\text { financing of health services and } \\
\text { determinants of fair financing } \\
\text { contribution }\end{array}$ & A cross-sectional study & Satisfactory & $\begin{array}{l}\text { Rate for Out of Payments } \\
\text { health expenditure }\end{array}$ \\
\hline $\begin{array}{l}\text { Ghiasvand H, Naghdi S, } \\
\text { Abolhassani N, } \\
\text { Shaarbafchizadeh N, Moghri } \\
\text { J.(119) }\end{array}$ & $\begin{array}{l}\text { This study investigated the Iranian } \\
\text { rural and urban households' } \\
\text { inequality in payments on food and } \\
\text { OOP health expenditures }\end{array}$ & $\begin{array}{l}\text { A cross-sectional time trend } \\
\text { study }\end{array}$ & Good & $\begin{array}{l}\text { Concentration Indices for } \mathrm{F} \\
\text { Health Expenditure }\end{array}$ \\
\hline $\begin{array}{l}\text { Ghafoori MH, Ebadifard Azar } \\
\text { F, Arab M, Mahmoodi M, } \\
\text { Yusef Zadeh N, Rezapour } \\
\text { A.(120) }\end{array}$ & $\begin{array}{l}\text { To determine disparities in health } \\
\text { expenditures by means of different } \\
\text { approaches }\end{array}$ & $\begin{array}{l}\text { A cross-sectional population- } \\
\text { based study }\end{array}$ & Satisfactory & $\begin{array}{l}\text { Fairness in Financial Contril } \\
\text { Concentration Index } \\
\text { Catastrophic Health Expend }\end{array}$ \\
\hline
\end{tabular}

tion by policymakers in Iran. In particular, insurance policies need serious reforms to cover needed and evidence-informed benefit packages, purchaser-provider split, factbased premium calculation, and progressive approaches to cover the poor living in rural and deprived areas $(110,135$, 136).

\section{Study limitations}

Health equity includes a vast range of topics; thus, conducting just a systematic review cannot show the details of the studies. Therefore, it is better to conduct several systematic reviews on the aspect of health equity to achieve better results. We considered all aspects of health equity 
Table 4. Ctd

\begin{tabular}{|c|c|c|c|c|}
\hline Citation & Aims & $\begin{array}{l}\text { Study De- } \\
\text { sign }\end{array}$ & $\begin{array}{c}\text { Newcastle-Ottawa } \\
\text { Scale }^{* *}\end{array}$ & Summary Results \\
\hline $\begin{array}{l}\text { Anbari Z, Mohammadbeigi A, } \\
\text { Mohammadsalehi N, Ebrazeh } \\
\text { A.(121) }\end{array}$ & $\begin{array}{l}\text { Evaluating some health expenditure of } \\
\text { inpatient and outpatient care as well as } \\
\text { assessing the predictors of catastrophic } \\
\text { costs for inpatient care }\end{array}$ & $\begin{array}{l}\text { A cross- } \\
\text { sectional } \\
\text { study }\end{array}$ & Good & Catastrophic Costs Ratio \\
\hline $\begin{array}{l}\text { Rezapour A, Vahedi S, Khiavi FF, } \\
\text { Esmaeilzadeh F, Javan-Noughabi J, } \\
\text { Rajabi A.(122) }\end{array}$ & $\begin{array}{l}\text { Analyzing CHE among households with } \\
\text { and without chronic NCDs }\end{array}$ & $\begin{array}{l}\text { A cross- } \\
\text { sectional } \\
\text { study }\end{array}$ & Satisfactory & $\begin{array}{l}\text { The Catastrophic Health } \\
\text { Expenditure incidence } \\
\text { and intensity in the } \\
\text { households with chronic } \\
\text { NCDs". }\end{array}$ \\
\hline \multirow[t]{3}{*}{$\begin{array}{l}\text { Ghiasvand H, Gorji HA, Maleki M, } \\
\text { Hadian M.(13) }\end{array}$} & \multirow{3}{*}{$\begin{array}{l}\text { To explore the mean of OOP payments } \\
\text { among Iranian households for health } \\
\text { services and the level of inequality in its } \\
\text { distribution }\end{array}$} & \multirow[t]{3}{*}{$\begin{array}{l}\text { A cross- } \\
\text { sectional } \\
\text { study }\end{array}$} & \multirow[t]{3}{*}{ Good } & $\begin{array}{l}\text { The Catastrophic Health } \\
\text { Expenditure headcount } \\
\text { ratio }\end{array}$ \\
\hline & & & & The overshoot of \\
\hline & & & & $\begin{array}{l}\text { Catastrophic Health } \\
\text { Expenditure ratio }\end{array}$ \\
\hline $\begin{array}{l}\text { Rezapour A, Azar FE, Aghdash } \\
\text { SA, Tanoomand A, Ahmadzadeh } \\
\text { N, Asiabar AS.(123) }\end{array}$ & $\begin{array}{l}\text { To assess the inequality in household's } \\
\text { capacity to pay and OOP health care } \\
\text { payments }\end{array}$ & $\begin{array}{l}\text { A cross- } \\
\text { sectional } \\
\text { study }\end{array}$ & Good & $\begin{array}{l}\text { Concentration Index for } \\
\text { household's Out-of- } \\
\text { Pocket payments }\end{array}$ \\
\hline $\begin{array}{l}\text { Rezapour A, Azar FE, Aghdash } \\
\text { SA, Tanoomand A, Shokouh SMH, } \\
\text { Yousefzadeh N, et al. (124) }\end{array}$ & $\begin{array}{l}\text { Measuring equity in household's health } \\
\text { care payments according to FFCI and } \\
\text { Kakwani indices }\end{array}$ & $\begin{array}{l}\text { A cross- } \\
\text { sectional } \\
\text { study }\end{array}$ & Good & $\begin{array}{l}\text { "The Fairness in } \\
\text { Financial Contribution } \\
\text { Index for households in } \\
\text { health financing The } \\
\text { Kakwani index }\end{array}$ \\
\hline $\begin{array}{l}\text { Ghiasvand H, Sha'baninejad H, } \\
\text { Arab M, Rashidian A.(125) }\end{array}$ & $\begin{array}{l}\text { To calculate the proportion of } \\
\text { hospitalized patients exposed to } \\
\text { catastrophic medical payments }\end{array}$ & $\begin{array}{l}\text { A cross- } \\
\text { sectional } \\
\text { study }\end{array}$ & Good & $\begin{array}{l}\text { Ratio and likelihood of } \\
\text { exposure to Catastrophic } \\
\text { Health Expenditure }\end{array}$ \\
\hline $\begin{array}{l}\text { Ibrahimipour H, Maleki M-R, } \\
\text { Brown R, Gohari M, Karimi I, } \\
\text { Dehnavieh R. (126) }\end{array}$ & $\begin{array}{l}\text { To understand the Iranian health } \\
\text { financing system and provide lessons for } \\
\text { policy makers about achieving universal } \\
\text { coverage }\end{array}$ & $\begin{array}{l}\text { A } \\
\text { qualitative } \\
\text { study }\end{array}$ & Good & $\begin{array}{l}\text { There are seven major } \\
\text { obstacles to universal } \\
\text { coverage: } \\
\text { insured rate; regressive } \\
\text { financing and non- } \\
\text { transparent financial } \\
\text { flow; fragmented system; } \\
\text { non-scientifically } \\
\text { designed benefit package; } \\
\text { non-health-oriented and } \\
\text { expensive payment } \\
\text { system; uncontrolled } \\
\text { demands; and } \\
\text { administrative } \\
\text { deficiency". }\end{array}$ \\
\hline $\begin{array}{l}\text { Naghdi S, Moradi T, Tavangar F, } \\
\text { Bahrami G, Shahboulaghi M, } \\
\text { Ghiasvand H.(127) }\end{array}$ & $\begin{array}{l}\text { Investigating barriers to develop } \\
\text { financial protection as a requirement to } \\
\text { achieve universal health coverage }\end{array}$ & $\begin{array}{l}\text { A } \\
\text { qualitative } \\
\text { study }\end{array}$ & Satisfactory & $\begin{array}{l}\text { "The major themes } \\
\text { included the political, } \\
\text { social and economic } \\
\text { context of the country, the } \\
\text { context and structure of } \\
\text { healthcare system and } \\
\text { dimensions of UHC". }\end{array}$ \\
\hline
\end{tabular}

analysis in Iran, but extracting, summarizing, and reporting the retrieved evidence was a major challenge. Therefore, we have organized our research plan based on the current approaches of World Bank researchers. We used their classification approach for different topics in health equity analysis.

In addition, although primarily we ran search on the published studies in Persian language, based on our initial presumption and then the assessment of the retrieved studies, we decided to ignore them.

\section{Implications for Future Research}

We advocate the use of SDH perspective and other factors that affect health, including genetic and biological factors, food and nutrition, environmental and social factors, and even the impact of social and economic macro policies of the governments on health in studying health inequalities. Unless researchers study health inequalities through comprehensive lenses that accommodate social aspects, meaningful tackling

of such inequalities towards sustainable health development might be compromised.

\section{Conclusion}

This systematic review aimed to shed light on the various factors that contributed to health inequalities in Iran. Many studies approached the issue from the lenses of health system and focused on outcomes, utilization, and financial domains of inequalities as the main challenges to equity. Yet, the literature is tiny to accommodate the social problems that may be the cause of inequality in Iran. For instance, social issues such as unemployment, divorce, child labor, 
living in slums, and homelessness, which might be the consequences of social inequalities, need to be addressed while analyzing health inequalities in any settings.

In fact, policymakers in Iran need to develop directions in their health equity research priorities toward containing the factors that are not necessarily within the health system. Encouraging interdisciplinary research projects with social scientists is an urgent need.

Conflict of Interests

The authors declare that they have no competing interests.

Ethics approval and consent to participate: IR.TUMS. VCR.REC.1397.230.

\section{References}

1. Marmot M, Friel S, Bell R, Houweling TA, Taylor S, Health CoSDo. Closing the gap in a generation: health equity through action on the social determinants of health. Lancet. 2008;372(9650):1661-9.

2. Wagstaff A, O'Donnell O, Van Doorslaer E, Lindelow M. Analyzing health equity using household survey data: a guide to techniques and their implementation: World Bank Publications; 2007.

3. Bleich SN, Jarlenski MP, Bell CN, LaVeist TA. Health inequalities: trends, progress, and policy. Ann Rev Public Health. 2012;33:7-40.

4. Wagstaff A. Socioeconomic inequalities in child mortality: comparisons across nine developing countries. Bulletin of the World Health Organization. 2000;78(1):19-29.

5. Thomas SB, Quinn SC, Butler J, Fryer CS, Garza MA. Toward a fourth generation of disparities research to achieve health equity. Ann Rev Public Health.. 2011;32:399-416.

6. Grady SC, McLafferty S. Segregation, Nativity, and Health: Reproductive Health Inequalities for Immigrant and Native-Born Black Women in New York City1. Urban Geogr. 2007;28(4):377-97.

7. O'Donnell O, Van Doorslaer E, Wagstaff A, Lindelow M. Analyzing health equity using household survey data: a guide to techniques and their implementation: The World Bank; 2007.

8. Marmot SM. Closing the health gap in a generation: the work of the Commission on Social Determinants of Health and its recommendations. Glob Health Promot. 2009;16(1_suppl):23-7.

9. Moghaddam AV, Damari B, Alikhani S, Salarianzedeh M, Rostamigooran N, Delavari A, et al. Health in the 5th 5-years Development Plan of Iran: main challenges, general policies and strategies. Iran J Public Health. 2013;42(Supple1):42.

10. Motlagh M. Oliaei manesh AR, Beheshtian M. Health and its social determinants Tehran: Health policy council Secretariat of social determinant of health Ministry of Health and Medical Education. 2008.

11. Asadi-Lari M, Vaez-Mahdavi MR, Faghihzadeh S, Montazeri A, Farshad AA, Kalantari N, et al. The application of urban health equity assessment and response tool (Urban HEART) in Tehran concepts and framework. Med J Islam Repub Iran. 2010;24(3):175-85.

12. Rashidian A, Karimi-Shahanjarini A, Khosravi A, Elahi E, Beheshtian M, Shakibazadeh E, et al. Iran's multiple indicator demographic and health survey-2010: Study protocol. Int J Prev Med. 2014;5(5):632.

13. Ghiasvand H, Gorji HA, Maleki M, Hadian M. Catastrophic health expenditure among Iranian rural and urban households, 2013-2014. Iran Red Crescent Med J. 2015;17(9).

14. Stang A. Critical evaluation of the Newcastle-Ottawa scale for the assessment of the quality of nonrandomized studies in meta-analyses. Eur J Epidemiol. 2010;25(9):603-5.

15. cebm. https://www.cebm.net/wp-content/uploads/2019/01/ Systematic-Review.pdf 2020

16. cebm. https://www.cebm.net/wp-content/uploads/2019/01/ Qualitative-Studies.pdf. 2020.

17. Emamian MH, Fateh M, Hosseinpoor AR, Alami A, Fotouhi A. Obesity and its socioeconomic determinants in Iran. Econ Hum Biol. 2017;26:144-50

18. Farzadi F, Ahmadi B, Shariati B, Alimohamadian M, Mohamad K. Women's health: explaining the trend in gender ratio in Iran over half a century (1956-2006). Public Health. 2010;124(2):86-9.

19. Gooshki ES, Rezaei R, Wild V. Migrants' Health in Iran from the Perspective of Social Justice: a Systematic Literature Review. Arch Iran Med. 2016;19(10).

20. Moradi-Lakeh M, Bijari B, Namiranian N, Olyaeemanesh A-R,
Khosravi A. Geographical disparities in child mortality in the rural areas of Iran: 16-years trend. J Epidemiol Commun Health. 2013;67(4):3469.

21. Nedjat S, Hosseinpoor AR, Forouzanfar MH, Golestan B, Majdzadeh R. Decomposing socioeconomic inequality in self-rated health in Tehran. J Epidemiol Commun Health. 2012;66(6):495-500.

22. Emamian MH, Zeraati H, Majdzadeh R, Shariati M, Hashemi H, Jafarzadehpur E, et al. Economic inequality in presenting near vision acuity in a middle-aged population: a Blinder-Oaxaca decomposition. Br J Ophthalmol. 2013;97(9):1100-3.

23. Morasae EK, Forouzan AS, Majdzadeh R, Asadi-Lari M, Noorbala AA, Hosseinpoor AR. Understanding determinants of socioeconomic inequality in mental health in Iran's capital, Tehran: a concentration index decomposition approach. Int J Equity Health. 2012;11(1):18

24. Ramezani Doroh V, Vahedi S, Arefnezhad M, Kavosi Z, Mohammadbeigi A. Decomposition of health inequality determinants in Shiraz, South-West Iran. J Res Health Sci. 2015;15(3):152-8.

25. Shahbazi N, Veisani Y, Delpisheh A, Sayehmiri K, Naderi Z, Sohrabnejad A, et al. Relationship between Socioeconomic Status and General Health in the Female-headed Households. J Ilam Uni Med Sci. 2015;23(1):56-62.

26. Amirian H, Poorolajal J, Roshanaei G, Esmailnasab N, Moradi G. Analyzing socioeconomic related health inequality in mothers and children using the concentration index. Epidemiol Biostat Public Health. 2014;11(3).

27. Khajavi A, Pishgar F, Dehghani M, Naderimagham S. Socioeconomic inequalities in neonatal and postneonatal mortality: Evidence from rural Iran, 1998-2013. Int J Equity Health. 2017;16(1):83.

28. Alizadeh M, Laghousi D. Trend of geographical disparities in child and maternal mortality indicators in Northwest Iran. Soc Determ Health. 2015;1(4):132-40.

29. Rarani MA, Rashidian A, Arab M, Khosravi A, Abbasian E. Inequality in under-five mortality in Iran: a national and subnational survey data analysis. Glob J Health Sci. 2016;9(3):215.

30. Kiadaliri AA. Gender and social disparities in esophagus cancer incidence in Iran, 2003-2009: a time trend province-level study. Asian Pac J Cancer Prev. 2014;15(2):623-7.

31. Kiadaliri AA, Saadat S, Shahnavazi H, Haghparast-Bidgoli H. Overall, gender and social inequalities in suicide mortality in Iran, 2006-2010: a time trend province-level study. BMJ Open. 2014;4(8):e005227.

32. Ghorbani Z, Ahmady AE, Ghasemi E, Zwi A. Socioeconomic inequalities in oral health among adults in Tehran, Iran. Commun Dent Health. 2015;32(1):26-31.

33. Hosseinpoor AR, Mohammad K, Majdzadeh R, Naghavi M, Abolhassani F, Sousa A, et al. Socioeconomic inequality in infant mortality in Iran and across its provinces. Bull World Health Organ 2005;83(11):837-44.

34. Hosseinpoor AR, Van Doorslaer E, Speybroeck N, Naghavi M, Mohammad K, Majdzadeh R, et al. Decomposing socioeconomic inequality in infant mortality in Iran. Int J Epidemiol. 2006;35(5):12119.

35. Almasi-Hashiani A, Sepidarkish M, Safiri S, Morasae EK, Shadi Y, Omani-Samani R. Understanding determinants of unequal distribution of stillbirth in Tehran, Iran: a concentration index decomposition approach. BMJ Open. 2017;7(5):e013644.

36. Rad EH, Khodaparast M. Inequity in Health Care Financing in Iran: Progressive or Regressive Mechanism? Eurasian J Med. 2016;48(2): 112 .

37. Emamian MH, Zeraati H, Majdzadeh R, Shariati M, Hashemi H, Fotouhi A. Unmet refractive need and its determinants in Shahroud, Iran. Int J Ophthalmol. 2012;32(4):329-36.

38. Hosseinkhani Z, Nedjat S, Aflatouni A, Mahram M, Majdzadeh R. Socioeconomic inequality and child maltreatment in Iranian schoolchildren. East Mediterr Health J. 2015;21(11):819.

39. Mansouri A, Rarani MA, Fallahi M, Alvandi I. Irritable bowel syndrome is concentrated in people with higher educations in Iran: an inequality analysis. Epidemiol Health. 2017;39.

40. Fateh M, Emamian MH, Asgari F, Alami A, Fotouhi A. Socioeconomic inequality in hypertension in Iran. $\mathrm{J}$ Hypertens 2014;32(9):1782-8.

41. Moradi G, Ardakani HM, Majdzadeh R, Bidarpour F, Mohammad K, Holakouie-Naieni K. Socioeconomic inequalities in nonuse of seatbelts in cars and helmets on motorcycles among people living in Kurdistan Province, Iran. Iran J Public Health. 2014;43(9):1239.

42. Veisani Y, Delpisheh A, Moradi G, Hassanzadeh J, Sayehmiri K. 
Inequality in addiction and mental disorders in 6818 suicide attempts: determine of positive contribution of determinants by decomposition method. Iran J Public Health. 2017;46(6):796.

43. Tourani S, Zarezadeh M, Raadabadi M, Pourshariati F. Association of regional disparity of obstetrics and gynecologic services with children and infants mortality rates: A cross-sectional study. Int J Reprod Biomed. 2017;15(3):147.

44. Entezarmahdi R, Majdzadeh R, Foroushani AR, Nasehi M, Lameei A, Naieni KH. Inequality of leprosy disability in Iran, clinical or socioeconomic inequality: an extended concentration index decomposition approach. Int J Prev Med. 2014;5(4):414.

45. Moradi G, Mohammad K, Majdzadeh R, Ardakani HM, Naieni KH. Socioeconomic inequality of non-communicable risk factors among people living in Kurdistan Province, Islamic Republic of Iran. Int J Prev Med. 2013;4(6):671.

46. Naghdi S, Ghiasvand H, Zadeh NS, Azami S, Moradi T. Association of health and food expenditures inequality with health outcomes: a case study on Iranian rural households. Iran Red Crescent Med J. 2014;16(3).

47. Kiadaliri AA. Social disparity in breast and ovarian cancer incidence in iran, 2003-2009: a time trend province-level study. J Breast Cancer. 2013;16(4):372-7.

48. Kia AA, Rezapour A, Khosravi A, Abarghouei VA. Socioeconomic Inequality in Malnutrition in Under-5 Children in Iran: Evidence From the Multiple Indicator Demographic and Health Survey, 2010. J Prev Med Public Health. 2017;50(3):201

49. Moradi G, Moinafshar A, Adabi H, Sharafi M, Mostafavi F, Bolbanabad AM. Socioeconomic Inequalities in the Oral Health of People Aged 15-40 Years in Kurdistan, Iran in 2015: A Cross-sectional Study. J prev Med Public Health. 2017;50(5):303.

50. Kiadaliri AA, Asadi-Lari M, Kalantari N, Jafari M, Mahdavi MRV, Faghihzadeh S. Absolute and relative educational inequalities in obesity among adults in Tehran: Findings from the Urban HEART study-2. Obes Res Clin Pract. 2016;10:S57-S63.

51. Emamian MH, Zeraati H, Majdzadeh R, Shariati M, Hashemi H, Fotouhi A. The gap of visual impairment between economic groups in Shahroud, Iran: a Blinder-Oaxaca decomposition. Am J Epidemiol. $2011 ; 173(12): 1463-7$.

52. Hosseini M, Olyaeemanesh A, Ahmadi B, Nedjat S, Farzadi F, Arab $\mathrm{M}$, et al. Gender equity in health: A secondary analysis of data in Iran. Med J Islam Repub Iran. 2016;30:344.

53. Emamian MH, Fateh M, Gorgani N, Fotouhi A. Mother's education is the most important factor in socio-economic inequality of child stunting in Iran. Public Health Nutr. 2014;17(9):2010-5.

54. Raeisi A, Mehboudi M, Darabi H, Nabipour I, Larijani B, Mehrdad N, et al. Socioeconomic inequality of overweight and obesity of the elderly in Iran: Bushehr Elderly Health (BEH) Program. BMC Public Health. 2017;17(1):72.

55. Safiri S, Kelishadi R, Heshmat R, Rahimi A, Djalalinia S, Ghasemian $\mathrm{A}$, et al. Socioeconomic inequality in oral health behavior in Iranian children and adolescents by the Oaxaca-Blinder decomposition method: the CASPIAN-IV study. Int J Equity Health. 2016;15(1):143.

56. Peykari N, Djalalinia S, Qorbani M, Sobhani S, Farzadfar F, Larijani B. Socioeconomic inequalities and diabetes: A systematic review from Iran. J Diabetes Metab Disord Control. 2015;14(1):8.

57. Ravaghi H, Goshtaei M, Olyaee Manesh A, Abolhassani N, Arabloo J. Stakeholders' perspective on health equity and its indicators in Iran. Med J Islam Repub Iran.2015;29(1):713-23.

58. Zaboli R, Tourani S, Seyedin SH, Manesh AO. Prioritizing the determinants of social-health inequality in Iran: a multiple attribute decision making Iran Red Crescent Med J. 2014;16(4).

59. Beheshtian M, Manesh AO, Bonakdar S, Afzali HM, Larijani B, Hosseini L, et al. Intersectoral collaboration to develop health equity indicators in Iran. Iran J Public Health. 2013;42(Supple1):31.

60. Sadeghipour Roudsari H, Sherafat Kazemzadeh R, Rezaeie M, Derakhshan M. Reproductive health knowledge, attitudes and practices of Iranian and Afghan men in Tehran province.East Mediterr Health J. 2006;12(6):862-72.

61. Bidgoli HH, Bogg L, Hasselberg M. Pre-hospital trauma care resources for road traffic injuries in a middle-income country-A province based study on need and access in Iran. Injury. 2011;42(9):879-84.

62. Mohammadbeigi A, Hassanzadeh J, Eshrati B, Rezaianzadeh A. Decomposition of inequity determinants of healthcare utilization, Iran.
Public Health. 2013;127(7):661-7.

63. Mohammadbeigi A, Hassanzadeh J, Eshrati B, Rezaianzadeh A. Socioeconomic inequity in health care utilization, Iran. J Epidemiol Glob Health 2013;3(3):139-46.

64. Noroozi M, Rahimi E, Ghisvand H, Qorbani M, Sharifi H, Noroozi A, et al. Decomposition of Economic Inequality in Needle and Syringe Programs Utilization to its Determinants among Men Who Inject Drugs in Tehran using Blinder-Oaxaca Decomposition Method. Subst Use Misuse. 2017:1-7

65. Davari M, Maracy MR, Aslani A, Bakhshizadeh Z, Khorasani E. Evaluation of equity in access to pharmaceutical services in selected cites of Isfahan Province, Iran. Journal of Pharmacoeconomics and Pharmaceutical Management. 2017;2(1/2):25-9.

66. Ramandi SD, Niakan L, Aboutorabi M, Noghabi JJ, Khammarnia M, Sadeghi A. Trend of Inequality in the Distribution of Health Care Resources in Iran. Galen Medical Journal. 2016;5(3):122-30.

67. Kiadaliri AA, Najafi B, Haghparast-Bidgoli H. Geographic distribution of need and access to health care in rural population: an ecological study in Iran. Int J Equity Health. 2011;10(1):39.

68. Kavosi Z, Mohammadbeigi A, Ramezani-Doroh V, Hatam N, Jafari A, Firoozjahantighi A. Horizontal inequity in access to outpatient services among Shiraz City residents, Iran. J Res Health Sci. 2015;15(1):37-41.

69. Karyani AK, Azami SR, Rezaei S, Shaahmadi F, Ghazanfari S. Geographical distribution of gynecologists and midwives in Kermanshah province (2008-2013). J Kermanshah Univ Med Sci. 2015;19(5):294-302.

70. Meshkini AH, Kebriaeezadeh A, Janghorban MR, Keshavarz K, Nikfar S. Assessment of geographic accessibility to pharmacy in Qom, Iran: A geographic information system analysis. Thrita. 2014;3(1).

71. Hajizadeh M, Connelly LB, Butler JR, Khosravi A. Unmet need and met unneed in health care utilisation in Iran. Int $J$ Soc Econ. 2012;39(6):400-22.

72. Noroozi M, Sharifi H, Noroozi A, Rezaei F, Bazrafshan MR, Armoon B. Decomposing economic disparities in risky sexual behaviors among people who inject drugs in Tehran: Blinder-Oaxaca decomposition analysis. Epidemiol Health. 2017;39.

73. Geravandi S, Najafi M, Rajaee R, Mahmoudi S, Pakdaman M. The assessment of inequality in the geographical distribution of burn beds in Iran. Electron Physician. 2015;7(6):1407.

74. Sefiddashti SE, Arab M, Ghazanfari S, Kazemi Z, Rezaei S, Karyani AK. Trends of geographic inequalities in the distribution of human resources in healthcare system: the case of Iran. Electron physician. 2016;8(7):2607.

75. Honarmand R, Mozhdehifard M, Kavosi Z. Geographic distribution indices of general practitioners, midwives, pediatricians, and gynecologists in the public sector of Iran. Electron Physician. 2017;9(6):4584.

76. Moradi LM, Ramezani M, Naghavi M. Equality in safe delivery and its determinants in Iran. Arch Iran Med. 2007;10(4):446-51. 2007.

77. Meskarpour-Amiri M, Mehdizadeh P, Barouni M, Dopeykar N, Ramezanian M. Assessment the trend of inequality in the distribution of intensive care beds in Iran: using GINI index. Glob J Health Sci. 2014;6(6):28

78. Jadidi R, Mohammadbeigi A, Mohammadsalehi N, Ansari H, Ghaderi E. Inequity in timeliness of MMR vaccination in children living in the suburbs of Iranian cities. Int J Biomed Sci. 2015;11(2):93.

79. Masoodi M, Rahimzadeh M. Measuring access to urban health services using Geographical Information System (GIS): a case study of health service management in Bandar Abbas, Iran. Int $\mathrm{J}$ Health Policy Manag. 2015;4(7):439.

80. Emamian MH, Zeraati H, Majdzadeh R, Shariati M, Hashemi H, Fotouhi A. Economic inequality in eye care utilization and its determinants: a Blinder-Oaxaca decomposition. Int $\mathrm{J}$ Health Policy Manag. 2014;3(6):307.

81. Homaie Rad E, Ghiasi A, Arefnezhad M, Bayati M. Inequalities of general physicians and specialists visits' utilization and its determinants in Iran: a population based study. Int $\mathrm{J}$ Hum Rights Healthc. 2015;8(3):125-31.

82. Kazemi Karyani A, Kazemi Z, Shaahmadi F, Arefi Z, Ghazanfari S. Determining inequality and trend of geographic accessibility to pediatricians in Iran: 2007-2013. Int J Pediatr. 2015;3(2.1):51-8.

83. Meskarpour-Amiri M, Dopeykar N, Ameryoun A, Tavana AM. Assessment inequality in access to public cardiovascular health services in Iran. Med J Islam Repub Iran. 2016;30:420. 
84. Mobaraki H, Hassani A, Kashkalani T, Khalilnejad R, Chimeh EE. Equality in distribution of human resources: the case of Iran's Ministry of Health and Medical Education. Iran J Public Health. 2013;42(Supple1):161.

85. Omrani-Khoo H, Lotfi F, Safari H, Jame SZB, Moghri J, Shafii M. Equity in distribution of health care resources; assessment of need and access, using three practical indicators. Iran J Public Health. 2013;42(11):1299.

86. Sari AA, Rezaei S, Rad EH, Dehghanian N, Chavehpour Y. Regional disparity in physical resources in the health sector in Iran: a comparison of Two time periods. Iran J Public Health. 2015;44(6):848.

87. Mohammadbeigi A, Arsangjang S, Mohammadsalehi N, Anbari Z, Ghaderi E. Education-related inequity in access and utilization of oral health care in Iran. J Family Med Prim Care. 2015;4(1):35.

88. Rad EH, Kavosi Z, Arefnezhad M. Economic inequalities in dental care utilizations in Iran: Evidence from an urban region. Med J Islam Repub Iran. 2016;30:383.

89. Hatam N, Zakeri M, Sadeghi A, Ramandi SD, Hayati R, Siavashi E. Equity analysis of hospital beds distribution in Shiraz, Iran 2014. Med J Islam Repub Iran. 2016;30:393.

90. Ameryoun A, Meskarpour-Amiri M, Dezfuli-Nejad ML, KhoddamiVishteh H, Tofighi S. The assessment of inequality on geographical distribution of Non-cardiac intensive care beds in Iran. Iran J Public Health. 2011;40(2):25.

91. Hashemi H, Rezvan F, Fotouhi A, Khabazkhoob M, Gilasi H, Etemad $\mathrm{K}$, et al. Distribution of cataract surgical rate and its economic inequality in Iran. Optom Vis Sci. 2015;92(6):707-13.

92. Reshadat S, Saedi S, Zangeneh A, Ghasemi S, Gilan N, Karbasi A, et al. Spatial accessibility of the population to urban health centres in Kermanshah, Islamic Republic of Iran: a geographic information systems analysis. East Mediterr Health J. 2015;21(6):389.

93. Rezaei S, Karyani A, Fallah R, Matin B. Relative inequalities in geographic distribution of health care resources in Kermanshah province, Islamic Republic of Iran. East Mediterr Health J. 2016;22(1):20.

94. Chavehpour Y, Rashidian A, Raghfar H, Emamgholipour sefiddashti $\mathrm{S}$, Maroofi A. 'Seeking affluent neighbourhoods?'a time-trend analysis of geographical distribution of hospitals in the Megacity of Tehran. Health Policy Plan. 2017;32(5):669-75.

95. Nemati R, Seyedin H, Nemati A, Sadeghifar J, Nasiri AB, Mousavi $\mathrm{SM}$, et al. An analysis of disparities in access to health care in Iran: evidence from Lorestan Province. Glob J Health Sci. 2014;6(5):81.

96. Yari A, Nedjat S, Asadi-Lari M, Majdzadeh R. Perceptions about Iranian-Kurds' ethnic-inequality in health. BMC Int Health Hum Rights. 2017;17(1):24.

97. Mohammadi S, Gargari SS, Fallahian M, Källestål C, Ziaei S, Essén B. Afghan migrants face more suboptimal care than natives: a maternal near-miss audit study at university hospitals in Tehran, Iran. BMC Pregnancy Childbirth. 2017;17(1):64.

98. Rezapour A, Arabloo J, Tofighi S, Alipour V, Sepandy M, Mokhtari $\mathrm{P}$, et al. Determining Equity in Household's Health Care Payments in Hamedan Province, Iran. Arch Iran Med. 2016;19(7).

99. Rezapour A, Ghaderi H, Azar FE, Larijani B, Gohari MR. Effects of health out-of-pocket payment on households in iran; catastrophic and impoverishment: Population based study in Tehran (2012). Life Sci J. 2013; 10(3).

100. Zare H, Trujillo AJ, Driessen J, Ghasemi M, Gallego G. Health inequalities and development plans in Iran; an analysis of the past three decades (1984-2010). Int J Equity Health. 2014;13(1):42.

101. Davari M, Kheyri M, Nourbakhsh SMK, Khadivi R. Socioeconomic status and catastrophic health expenditure evaluation in IR Iran: A comparative study in 2004 and 2011. Social Determinants of Health. 2015;1(2):48-59.

102. Khammarnia M, Keshtkaran A, Kavosi Z, Hayati R. The Household Health Spending and Impoverishment: Findings from the Households Survey in Shiraz, Iran. Bangladesh Med Res Counc Bull. 2015;40(2):58-62.

103. Delavari H, Keshtkaran A, Setoudehzadeh F. Catastrophic health expenditures and coping strategies in households with cancer patients in Shiraz Namazi hospital. Middle East J Cancer. 2014;5(1):13-22.

104. Kavosi Z, Rashidian A, Pourreza A, Majdzadeh R, Pourmalek F, Hosseinpour AR, et al. Inequality in household catastrophic health care expenditure in a low-income society of Iran. Health Policy Plan. 2012;27(7):613-23.

105. Fazaeli AA, Seyedin H, Moghaddam AV, Delavari A, Salimzadeh H,
Varmazyar H, et al. Fairness of financial contribution in Iranian health system: Trend analysis of national household income and expenditure, 2003-2010. Glob J Health Sci. 2015;7(5):260.

106. Juyani Y, Hamedi D, Jebeli SSH, Qasham M. Multiple Sclerosis and Catastrophic Health Expenditure in Iran. Glob J Health Sci. 2016;8(9):194.

107. Hajizadeh M, Connelly LB. Equity of health care financing in Iran: the effect of extending health insurance to the uninsured. Oxf Dev Stud. 2010;38(4):461-76

108. Hajizadeh M, Nghiem HS. Out-of-pocket expenditures for hospital care in Iran: who is at risk of incurring catastrophic payments? Int J Health Econ Manag. 2011;11(4):267.

109. Reshadat S, Najafi F, Karami-Matin B, Soofi M, Barfar E, RajabiGilan N, et al. Measuring Financial Protection in Hospitalized Patients after the Health Sector Evolution Plan in Iran. Health Scope. 2017(In Press).

110. Ghorbanian A, Rashidian A, Lankarani KB, Kavosi Z. The Prevalence and Determinants of Catastrophic Health Expenditures in Iran: A Systematic Review and Meta-Analysis. Health Scope. 2017(In Press).

111. Ghoddoosinejad J, Jannati A, Gholipour K, Baghestan EB. Households encountering with catastrophic health expenditures in Ferdows, Iran. J Egypt Public Health Assoc. 2014;89(2):81-4.

112. Mansouri A, Emamian MH, Zeraati H, Hashemi H, Fotouhi A. Economic inequality in presenting vision in Shahroud, Iran: two decomposition methods. Int J Health Policy Manag. 2018;7(1):59.

113. Kavosi Z, Keshtkaran A, Hayati R, Ravangard R, Khammarnia M. Household financial contribution to the health System in Shiraz, Iran in 2012. Int J Health Policy Manag. 2014;3(5):243.

114. Piroozi B, Moradi G, Nouri B, Bolbanabad AM, Safari H. Catastrophic health expenditure after the implementation of health sector evolution plan: a case study in the west of Iran. Int J Health Policy Manag. 2016;5(7):417.

115. Rarani MA, Rashidian A, Khosravi A, Arab M, Abbasian E, Morasae EK. Changes in socio-economic inequality in neonatal mortality in Iran between 1995-2000 and 2005-2010: an Oaxaca decomposition analysis. Int J Health Policy Manag. 2017;6(4):219.

116. Daneshkohan A, Karami M, Najafi F, Matin BK. Household catastrophic health expenditure. Iran J Public Health. 2011;40(1):94.

117. Moghadam MN, Banshi M, Javar MA, Amiresmaili M, Ganjavi S Iranian household financial protection against catastrophic health care expenditures. Iran J Public Health. 2012;41(9):62.

118. Abolhallaje M, Hasani S, Bastani P, Ramezanian M, Kazemian M. Determinants of catastrophic health expenditure in Iran. Iran J Public Health. 2013;42(Supple1):155.

119. Ghiasvand H, Naghdi S, Abolhassani N, Shaarbafchizadeh N, Moghri J. Iranian Households' Payments on Food and Health Out-ofPocket Expenditures: Evidence of Inequality. Iran J Public Health. 2015;44(8):1103

120. Ghafoori MH, Ebadifard Azar F, Arab M, Mahmoodi M, Yusef Zadeh N, Rezapour A. Inequality in the Distribution of Health Expenditures in 22 Districts of Tehran. J Commun Health Res. 2014;3(2):132-44.

121. Anbari Z, Mohammadbeigi A, Mohammadsalehi N, Ebrazeh A. Health expenditure and catastrophic costs for inpatient-and out-patient care in Iran. Int J Prev Med. 2014;5(8):1023.

122. Rezapour A, Vahedi S, Khiavi FF, Esmaeilzadeh F, Javan-Noughabi J, Rajabi A. Catastrophic health expenditure of chronic diseases: Evidence from Hamadan, Iran. Int J Prev Med. 2017;8.

123. Rezapour A, Azar FE, Aghdash SA, Tanoomand A, Ahmadzadeh N, Asiabar AS. Inequity in household's capacity to pay and health payments in Tehran-Iran-2013. Med J Islam Repub Iran. 2015;29:245.

124. Rezapour A, Azar FE, Aghdash SA, Tanoomand A, Shokouh SMH, Yousefzadeh N, et al. Measuring equity in household's health care payments (Tehran-Iran 2013): technical points for health policy decision makers. Med J Islam Repub Iran. 2015;29:246.

125. Ghiasvand H, Sha'baninejad H, Arab M, Rashidian A. Hospitalization and catastrophic medical payment: evidence from hospitals located in Tehran. Arch Iran Med. 2014;17(7).

126. Ibrahimipour H, Maleki M-R, Brown R, Gohari M, Karimi I, Dehnavieh R. A qualitative study of the difficulties in reaching sustainable universal health insurance coverage in Iran. Health policy Plan. 2011;26(6):485-95.

127. Naghdi S, Moradi T, Tavangar F, Bahrami G, Shahboulaghi M, Ghiasvand H. The barriers to achieve financial protection in Iranian 
health system: a qualitative study in a developing country. Ethiop J Health Sci. 2017;27(5):491-500.

128. Olyaee MA, Haghdoust AA, Beheshtian M, Tehrani BA, Motlagh M. Progress towards health equity in IR of Iran through last three decades. 2009. Iran J Public Health. 38(Supple 1):130-135.

129. Ravaghi H, Goshtaei M, Manesh AO, Abolhassani N, Arabloo J. Stakeholders' perspective on health equity and its indicators in Iran: a qualitative study. Med J Islam Repub Iran. 2015;29:250.

130. Peykari N, Hashemi H, Dinarvand R, Haji-Aghajani M, Malekzadeh $\mathrm{R}$, Sadrolsadat A, et al. National action plan for non-communicable diseases prevention and control in Iran; a response to emerging epidemic. Diabetes Metab Disord. 2017;16(1):3.

131. Abbasi SH, Sundin Ö, Jalali A, Soares J, Macassa G. Ethnic Differences in the Risk Factors and Severity of Coronary Artery Disease: a Patient-Based Study in Iran. J Racial Ethn Health Disparities. 2017:1-9.

132. Piroozi B, Rashidian A, Takian A, Amerzadeh M, Sakha MA, Faraji $\mathrm{O}$, et al. The impact of health transformation plan on hospitalization rates in Iran: An interrupted time series. Int J Health Plann Manage. 2018.

133. Mohamadi E, Tabatabaei SM, Olyaeemanesh A, Sagha SF, Zanganeh M, Davari M, et al. Coverage Decision-Making for Orthopedics Interventions in the Health Transformation Program in Iran: A Multiple Criteria Decision Analysis (MCDA). Shiraz E-Medic J. 2016;17(12).

134. Rezaei S, Bazyar M, Fallah R, Chavehpour Y, Rad EH. Assessment of need and access to physician and hospital beds: a cross sectional province based study in Iran. Shiraz E-Medic J. 2015;16(6).

135. Aryankhesal A, Etemadi M, Mohseni M, Azami-Aghdash S, Nakhaei

M. Catastrophic Health Expenditure in Iran: A Review Article. Iran J Public Health. 2018;47(2):166.

136. Takian A, Rashidian A, Doshmangir L. The experience of purchaserprovider split in the implementation of family physician and rural health insurance in Iran: an institutional approach. Health Policy Plan. 2015;30(10):1261-71. 
Appendix

Search strategy:

- PubMed/MedLine:

(c(c(c(c(c(c(c(c(("health"[MeSH Terms] OR "health"[All Fields]) OR ("delivery of health care"[MeSH Terms] OR ("delivery"[All Fields] AND "health"[All Fields] AND "care"[All Fields]) OR "delivery of health care"[All Fields] OR ("health"[All Fields] AND "care"[All Fields]) OR "health care"[All Fields])) OR ("health services"[MeSH Terms] OR ("health"[All Fields] AND "services"[All Fields]) OR "health services"[All Fields])) OR ("health resources"[MeSH Terms] OR ("health"[All Fields] AND "resources"[All Fields]) OR "health resources"[All Fields])) OR (("health"[MeSH Terms] OR "health"[All Fields]) AND outcome[All Fields])) OR (("health"[MeSH Terms] OR "health"[All Fields]) AND consequences[All Fields])) AND equity[All Fields]) OR equality[All Fields]) OR disparity[All Fields]) OR ("socioeconomic factors"[MeSH Terms] OR ("socioeconomic"[All Fields] AND "factors"[All Fields]) OR "socioeconomic factors"[All Fields] OR "inequality"[All Fields])) OR inequity[All Fields]) OR accessibility[All Fields]) OR availability[All Fields]) OR acceptability[All Fields]) OR ("statistics and numerical data"[Subheading] OR ("statistics"[All Fields] AND "numerical"[All Fields] AND "data"[All Fields]) OR "statistics and numerical data"[All Fields] OR "utilization"[All Fields])) OR ("health expenditures"[MeSH Terms] OR ("health"[All Fields] AND "expenditures"[All Fields]) OR "health expenditures"[All Fields] OR "expenditure"[All Fields])) OR ("compensation and redress"[MeSH Terms] OR ("compensation"[All Fields] AND "redress"[All Fields]) OR "compensation and redress"[All Fields] OR "payment"[All Fields])) OR fairness[All Fields]) OR (horizontal[All Fields] AND equity[All Fields])) OR (vertical[All Fields] AND equity[All Fields])) AND ("iran"[MeSH Terms] OR "iran"[All Fields])

- Cochrane Library:

\#1 Health

\#2 Health Services

\# 3 Health Care

\#4 Health Outcomes

\#5 Health Consequences

\#6 Health System

\#7 Health Resources

\#8 Availability

\#9 Accessibility

\#10 Utilization

\#11 Expenditure

\#12 Payments

\# 13 Equity

\#14 Inequity

\# 15 Equality

\#16 Inequality

\#17 Fairness

\#18 Disparity

\#19 Acceptability

\#20 \#1 OR \#2 OR \#3 OR \#4 OR \#5 OR \#6 OR \#7

\#21 \#8 OR \#9 OR \#10 OR \#11 OR \#12

\#22 \#13 OR \#14 OR \#15 OR \#16 OR \#17 OR \#18 OR \#19

\#23 \#20 AND \#21 AND \#22 